\title{
Water and Land as Shared Resources for Agriculture and Aquaculture: Insights from Asia
}

\author{
Steven G. Pueppke ${ }^{1,2,3, * \mathbb{D}}$, Sabir Nurtazin ${ }^{4}$ and Weixin $\mathrm{Ou}^{5}$ \\ Center for Global Change and Earth Observations, Michigan State University, East Lansing, MI 48823, USA \\ Center for European, Russian and Eurasian Studies, Michigan State University, East Lansing, MI 48824, USA \\ NAU-MSU Asia Hub, Nanjing Agricultural University, Nanjing 210095, China \\ 4 Faculty of Biology and Biotechnology, al-Farabi Kazakh National University, Almaty 050040, Kazakhstan; \\ nurtazin.sabir@gmail.com \\ 5 College of Land Management, Nanjing Agricultural University, Nanjing 210095, China; owx@njau.edu.cn \\ * Correspondence: pueppke@msu.edu; Tel.: +1-269-888-1150
}

Received: 3 September 2020; Accepted: 4 October 2020; Published: 7 October 2020

check for updates

\begin{abstract}
Although agriculture and aquaculture depend on access to increasingly scarce, shared water resources to produce food for human consumption, they are most often considered in isolation. We argue that they should be treated as integrated components of a single complex system that is prone to direct or indirect tradeoffs that should be avoided while also being amenable to synergies that should be sought. Direct tradeoffs such as competition for space or the pollution of shared water resources usually occur when the footprints of agriculture and aquaculture overlap or when the two practices coexist in close proximity to one another. Interactions can be modulated by factors such as hydropower infrastructure and short-term economic incentives, both of which are known to disrupt the balance between aquaculture and agriculture. Indirect tradeoffs, on the other hand, play out across distances, i.e., when agricultural food sources are diverted to feed animals in aquaculture. Synergies are associated with the culture of aquatic organisms in rice paddies and irrigation waters, seasonal rotations of crop cultivation with aquaculture, and various forms of integrated agriculture-aquaculture (IAA), including jitang, a highly developed variant of pond-dike IAA. Policy decisions, socioeconomic considerations, and technology warrant increased scrutiny as determinants of tradeoffs and synergies. Priority issues for the future include guiding the expansion of aquaculture from its traditional base in Asia, taking advantage of the heterogeneity that exists within both agricultural and aquaculture systems, the development of additional metrics of tradeoffs and synergies, and adapting to the effects of climate change.
\end{abstract}

Keywords: water-energy-food; fish ponds; rice-fish; shrimp farming; Mekong River; dam construction; Central Asia; irrigation

\section{Introduction}

The challenge of understanding the complexity and resilience of the earth's natural systems has been made more difficult in recent years by human activities, which are modifying and increasingly disrupting natural processes [1]. Nowhere are these issues more evident than in the tangled relationship between two resources essential for all life: water and food [2]. The combination of a growing human population and rising living standards is placing demands on the planet to deliver more and more food, even as concerns mount about the availability of water to ensure that it is produced. These dynamics are heightening awareness of planetary limits and drawing attention to the consequences of synergies and tradeoffs. A number of conceptual frameworks have been conceived to address the above relationships. Among them are the well-known water-energy-food (WEF) nexus [3-6] and other frameworks that add 
emphasis to factors such as land use, climate, and ecosystem services [7-9]. All underscore the need for a systems approach to the food-water challenge, with priority assigned to detailed understanding of the interrelationships among the individual components of the system.

Water has responded to the above conceptual challenges by creating a new section on Water, Agriculture, and Aquaculture. In keeping with the journal's scope, the goal is to provide a high-quality outlet for research on the interrelationships between the land- and water-based production of food and the water resources that enable people to be fed. Particular emphasis is given to aquaculture, which although the world's most vibrant and rapidly growing food sector [10,11], is often under-appreciated in considerations of food systems [12-14]. Here, we examine the co-dependencies of agriculture and aquaculture on land and water resources. It is self-evident that these resources are shared and thus subject to tradeoffs and synergies $[15,16]$, but although aquaculture-agriculture interrelationships are apparent, the underlying dynamics have received insufficient attention and warrant additional investigation.

In addressing this subject, we emphasize Asia-not just the continent's moist, humid areas, but also the arid Central Asian region. Asia is a significant agricultural producer and also by far the dominant player in aquaculture, with nearly a $90 \%$ share of worldwide aquaculture production $[17,18]$. More than anywhere else, significant levels of agriculture and aquaculture coexist in Asia, where they depend on the same finite land and water resources. Asia is also undergoing rapid population growth, economic development, and urbanization-all of which stress water and food systems but also stimulate innovation. Our intent is not to be comprehensive or delve deeply into technical detail. Rather, we use case studies and other examples to point out interrelationships that have been under-appreciated and even overlooked. Some are synergistic, some represent tradeoffs, and all warrant further study. We seek to stimulate further thought about Water, Agriculture, and Aquaculture, not just on one continent, but also elsewhere across the globe [19].

There is little need to introduce agriculture in the context of our analysis. Land-based production of food-and although not emphasized here, of biomass used for fiber and energy—has a lengthy history [20]. Farming is a dominant feature of the landscape wherever edaphic and environmental conditions are appropriate and is generally familiar to most people. There is an exceptionally wide variation in the scale of crop-based agriculture, the degree to which it is intensive, and the extent to which it consumes water. Although just a few major crops provide the lion's share of human food needs, there are hundreds of other crops of lesser, but nonetheless significant value as food, often under localized conditions [21]. Each crop has its own specialized growth requirements, and many have benefitted from decades and sometimes centuries of genetic and agronomic improvement [22]. Agriculture produces food for direct human consumption, but as described below, it is also an important source of feed for terrestrial and aquatic animals that are raised for food.

Although aquaculture also has a long and rich history, it has only recently assumed major significance as a food source, and then in only some geographies [18,23-27]. The statement "Beyond wild fish: the rise of aquaculture" is a reminder that the depletion of wild fish stocks is the major driver for the rapid growth of aquaculture [28]. In this respect, the recent and ongoing transition from capture fisheries to aquaculture parallels the ancient transition from hunting and gathering to sedentary, crop-based agriculture [29]. This large time differential means that with few exceptions, aquaculture has not benefitted from the long-term technical and other improvements that characterize agriculture.

Nevertheless, aquaculture is adaptable to fresh, brackish, and saline water and can support a wide range of finfish species, as well as crustaceans and other animals. As with agriculture, it is highly diverse [30-32], accommodating wide variation in scope, scale, and management options (Table 1). Although fully closed systems removed from the natural environment are available, they are not treated in detail here. These systems are efficient and have desirable attributes (Table 1), but most existing aquaculture facilities rely on cages, pens, and ponds [18,32]. For example, in China, ponds accounted for more than $70 \%$ of total aquaculture production as of 2013 [14]. Open and partially closed aquaculture facilities are illustrated in Figure 1 and can be sited in coastal areas, in and near 
inland water bodies, and in climatic zones ranging from deserts to tropical monsoon regions [32,33]. Thus, the variability of aquaculture matches that of agriculture, and this creates significant potential for interactions as the two systems draw upon land and water resources [29]. Undesirable tradeoffs, tensions, and conflicts are inevitable and are considered in Section 2. There are also examples of highly beneficial synergistic interrelationships. These are discussed in Section 3.

Table 1. Diversity of aquaculture systems.

\begin{tabular}{cc}
\hline System (examples) & Characteristics \\
\hline $\begin{array}{c}\text { Open } \\
\text { (Enclosures in lakes, rivers, and reservoirs) }\end{array}$ & $\begin{array}{c}\text { Relies on natural processes } \\
\text { Investment ranges from low to high } \\
\text { Scalable, can be made intensive }\end{array}$ \\
\hline Partially closed & $\begin{array}{c}\text { Suitable for smallholders } \\
\text { Extensive to highly intensive }\end{array}$ \\
(Ponds, irrigation canals, flooded agricultural fields) & Amenable to integrated agriculture-aquaculture (IAA) \\
\hline Fully closed & $\begin{array}{c}\text { Complete environmental control } \\
\text { High efficiency and productivity }\end{array}$ \\
\hline
\end{tabular}

\section{Tradeoffs over Shared Resources}

Although tradeoffs between aquaculture and agriculture take various forms, they can be generally separated into two distinct categories. The first encompasses interactions that are direct in a spatial sense and that typically arise when crop-based agriculture coexists in close proximity to open or partially closed aquaculture. Included in this category is interference over the consumption of water or use of land as well as the generation of pollution and other externalities that are often not borne by the aquaculture or agriculture producer $[34,35]$. The second category encompasses indirect issues such as competition for inputs or consumption of agricultural products to feed organisms raised in aquaculture. The physical proximity of agriculture and aquaculture is usually not a major driver for indirect tradeoffs. Boundaries between the two categories are nevertheless fluid, and thus, although the direct-indirect dichotomy is useful for organization and analysis, the two categories are not mutually exclusive, as will become apparent in the discussion below.

\subsection{Tradeoffs between Agriculture and Open Aquaculture}

Most open aquaculture utilizes cages and pens erected in lakes, rivers, and reservoirs or in marine waters [18]. Interference with agriculture is unlikely offshore in maritime waters, but it occurs frequently in association with inland water bodies, even though open aquaculture does not directly compete for land and is considered to be non-consumptive of water [36]. Conflicts usually relate to water quality rather than quantity. Fecal material and uneaten feed from inappropriately designed and located aquaculture enclosures adds sediments and nutrients, principally nitrogen and phosphorus, to the surrounding water $[37,38]$. Fertilizers and other organic materials are sometimes even added to open water to encourage the growth of phytoplankton for fish consumption $[14,39,40]$. These practices accelerate eutrophication and can severely diminish water quality, especially when fish stocking levels are high and management is suboptimal $[10,26,41]$. In spite of recent efforts to improve management practices, open aquaculture is still considered to be a major cause of lowered quality of the surrounding water resource [42-45].

Pollution from agriculture is a second, well-known contributor to reduced water quality, including that in rivers, lakes, and reservoirs used for aquaculture [34,46,47]. The damage occurs when runoff from fields carries nitrogen and phosphorus, sediments, and other residues into nearby water bodies, with undesirable effects that parallel those attributed to aquaculture [48]. The degradation of water quality by both aquaculture and agriculture has consequently generated considerable concern, not because the two practices conflict with one another, but rather because they act in concert to compromise 
the aquatic environment [40,49-51]. This often leads to imposition of rules that stringently regulate or even ban whichever practice is viewed as the major threat to the shared resource [52-56].

Tradeoffs of this sort are most pronounced in China, where eutrophication is widespread, severe, and of national concern. Governmental policies to prevent the release of pollutants from agriculture into water bodies include the establishment of ecological red line buffers surrounding lakes, programs to return erodible farmland to natural vegetation, and proposals to limit the fertilization of crops [54,57-59]. Nevertheless, agriculture often retains priority for water [60]. Thus, aquaculture has been prohibited in some eutrophic lakes and significantly constrained in others, including Lake Taihu, which is known to receive nutrient loads from agriculture that exceed those from aquaculture $[52,54,61]$. Regulations have been adopted to ban the fertilization of open water, confine aquaculture to certain lake zones, prohibit feeding of caged fish, and even specify the species composition of fish allowed to be grown in confinement [14,62-66]. Thus, in end effect, concern for water quality has triggered not only complex interplay that mediates interference between agriculture and open aquaculture but also policies that often disadvantage aquaculture.

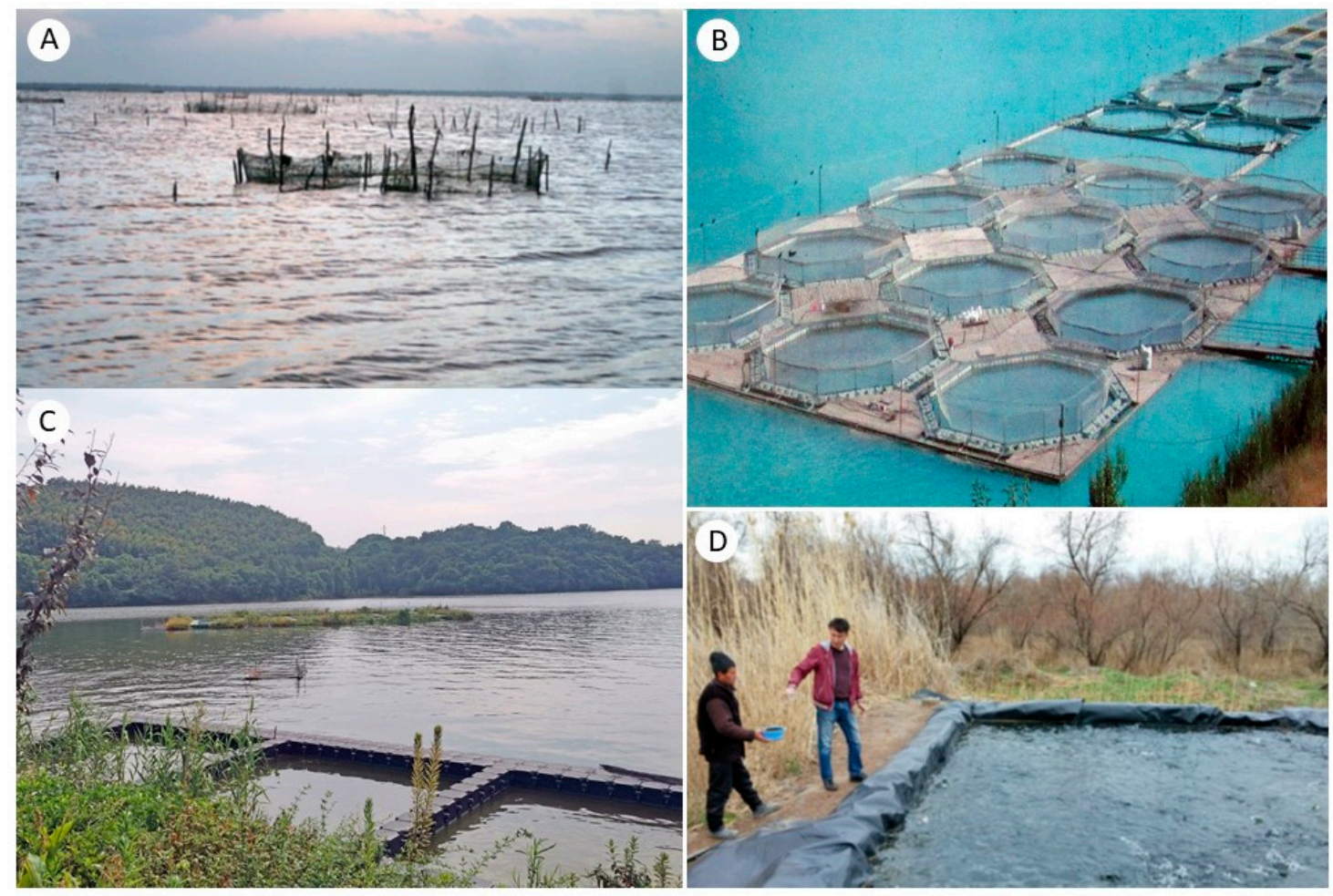

Figure 1. Examples of aquaculture facilities. (A). Simple fish cages in Sri Lanka. (B). Modern intensively managed fish pens in Uzbekistan. (C). Modular fish enclosures in China. (D). Plastic-lined fish pond in Kazakhstan. Picture credits: (A) and (D), S. Pueppke; (B), N. Graham; (C), W. Zhang.

\subsection{Tradeoffs between Semi-Closed Aquaculture and Agriculture}

The practice of siting ponds for semi-closed aquaculture on high-quality farmland has been discouraged [45], because it represents an obvious, avoidable offset in the capacity to produce food. Although the amount of land sacrificed for aquaculture may be relatively modest [34,67], the replacement of farmland with aquaculture ponds is nonetheless a controversial subject across southeast Asia, where economic conditions favor the conversion of farmland to fish ponds [68-71]. This has prompted countries such as Myanmar and Vietnam to attempt to constrain the practice so that crop production can be maintained $[69,72,73]$. Interference is an especially sensitive issue in China, where arable land is limited, land preservation for grain production is a national priority, and aquaculture is officially recognized as a source of land loss [28,74,75]. More than 225,000 ha of 
China's cultivated land, much of it in fertile coastal provinces, were nevertheless converted to fish ponds between just 1988 and 1995 [75], but countervailing forces are also at play. Thus, aquaculture ponds and freshwater lakes are routinely drained to create arable land and construction areas [76,77], and the drained land is also sometimes re-flooded [76,78]. Tradeoffs can also take the form of direct competition for scarce groundwater resources in arid areas such as China's far western Xinjiang Autonomous Region [79].

Although there have been calls for zoning laws and other policy measures to avoid direct tradeoffs between the land footprint of agriculture and the water footprint of ponds for aquaculture, tension between the two systems persists, especially in rapidly developing areas $[28,71,80]$. Nevertheless, either/or tensions mask more nuanced interactions that are conditioned by proximity and the partial overlap of agriculture and aquaculture. These occur when aquaculture management practices come into conflict with agricultural production on nearby land. The temporal and spatial dimensions of such interference can be illustrated by considering the dynamics of shrimp farming in rice-growing areas.

The cultivation of saltwater shrimp in Asia's coastal and inner coastal areas, including river deltas, has expanded significantly in recent decades, with well-known environmental consequences for mangroves and other biota $[30,67,68,81]$. There are also important consequences for agriculture, especially in countries such as Thailand, Bangladesh, and Vietnam [82]. For example, interference between agriculture and aquaculture is pronounced in inland areas of Thailand, where rice is grown extensively with irrigation that traditionally relies on water that is available without cost $[83,84]$. Saltwater naturally intrudes into these areas during the dry season, and it can be retained in ponds and mixed with freshwater during the wet season to create favorable growth conditions for saltwater shrimp. The resulting pollution of irrigation water and agricultural soils due to the seepage and release of water from ponds became severe in the 1990s [85]. The Thai government responded by banning shrimp aquaculture in some areas in 1998, but enforcement has been spotty [86]. Economic incentives favor shrimp to the extent that hypersaline water and even bagged salt are trucked in to maintain growth conditions for shrimp, with predictable detrimental effects on nearby agriculture [86].

Rice has also been extensively cultivated in coastal areas of Bangladesh since the 1960s, when polders and embankments were constructed to block saltwater intrusion from the tidal flows that occur year round $[87,88]$. Favorable market conditions began to make shrimp attractive in the 1970s and 1980s. This was initially accommodated by growing rice during the monsoon season, when freshwater is abundant, and culturing shrimp during the dry season, when salinity levels are naturally high [88-91]. Over time, this balance shifted to favor shrimp, which has largely supplanted rice and is now cultured continuously rather than seasonally in many areas $[89,92,93]$. Shrimp aquaculture in Bangladesh relies on trapped seawater that is swept inland through natural and engineered channels by tides. The ponds accumulate sediments from upstream runoff and also allow water to escape via percolation and overflow. Water is also routinely released during the growth season, and the contents of ponds are pumped out onto adjacent land at the end of each annual cycle of shrimp culture [94,95]. The combination of sedimentation and release of saltwater from ponds in this way degrades soils and can ultimately render them unfit for agriculture [91,96-98].

Islam and Tabeta [89] recently examined these dynamics by comparing the response of agriculture in the Rampal and Dumaria sub-districts of southwestern Bangladesh to the introduction of pond aquaculture about forty years ago. The environment in Rampal is suitable for shrimp culture, which replaced most agriculture after a short transition period during which both practices coexisted (Figure 2A). Dumaria, on the other hand, is more suitable for freshwater prawn, which was introduced in the 1990s and coexists with rather than competes with agriculture (Figure 2B). Temporal differences in agricultural production per ha are obvious: the trend is upward in Dumaria (Figure 2D), where soil quality has been preserved, but it is downward in Rampal (Figure 2C), where soils have become saline [89].

Depending on location, the effects of salinity can be compounded by soil acidification, the pollution of groundwater, land subsidence, and other hydrological perturbations-all of which can reinforce shifts 
away from agriculture $[45,70,83,86,95,99-101]$. Although some of these factors can be reversed over time, the salinization of soils is difficult to mitigate; thus, the economic benefits of shrimp culture [94,95], which are sometimes transient [70], may not extend to the long-term. Thus, the precarious balance between agriculture and aquaculture involves tradeoffs that depend strongly on localized environmental factors coupled to economic stimuli [102]. Farmers are often left with a stark choice: they can continue to culture of shrimp or take steps to control the salinization of croplands and maintain agriculture. As might be expected, these contrasting dynamics are leading to serious social impacts for residents of the affected areas $[93,103-105]$.
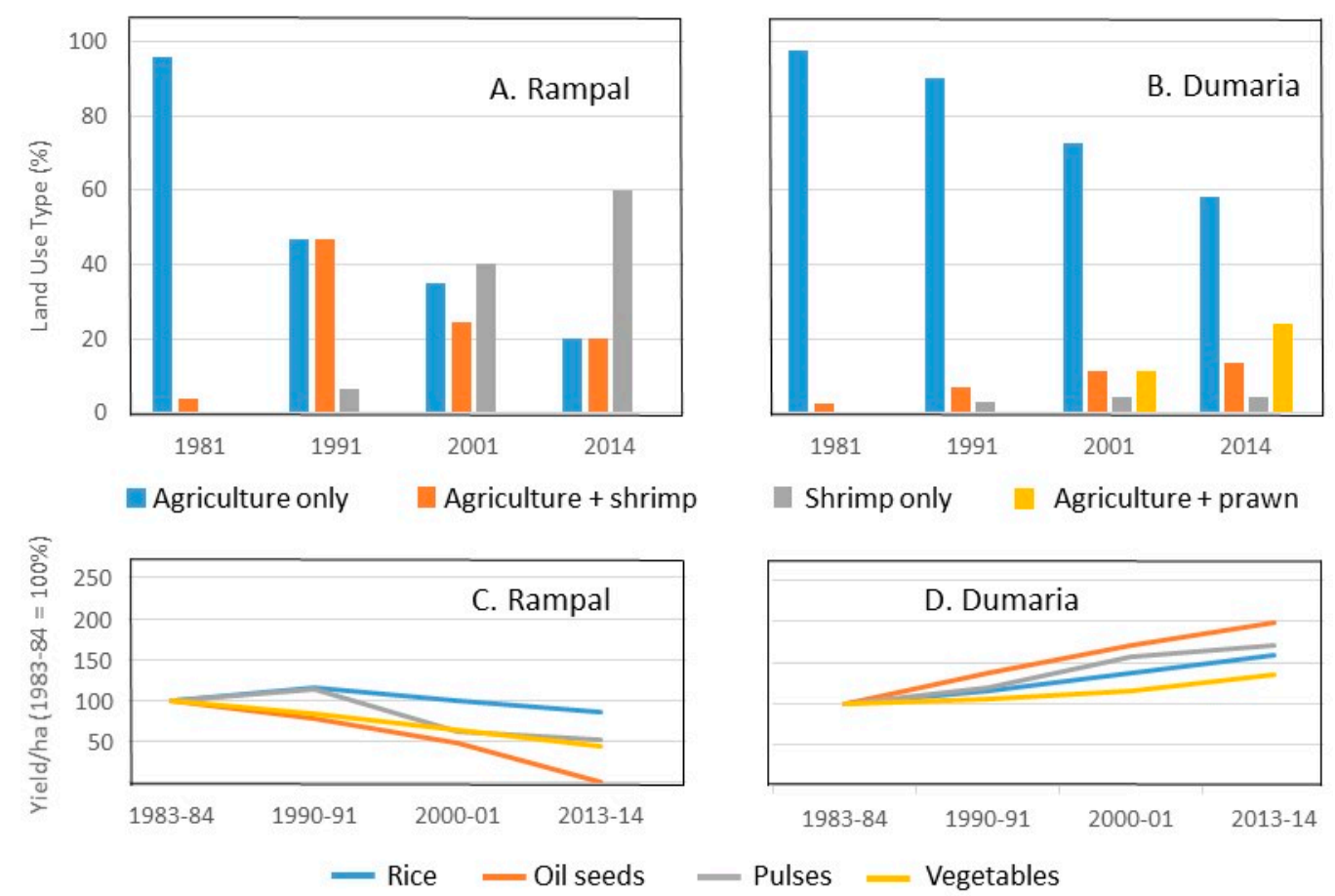

Figure 2. Changes in land use between 1981 and 2014 in the Rampal (A) and Dumaria (B) sub-districts of Bangladesh as well as trends in crop production/ha in Rampal (C) and Dumaria (D) from 1983-1984 to 2013-2014. The original data are from Islam and Tabita [89].

Similar tradeoffs between agriculture and aquaculture extend across Asia, including Indonesia, Myanmar, Vietnam, and Taiwan [68,88,99,103,106-108] and are being exacerbated-often across great distances-by the construction of hydroelectric dams. The hydrological changes brought on by impoundment of rivers such as the Mekong inevitably lead to conflicts between energy and other economic interests [109], including agriculture and aquaculture [110-115]. Although these dynamics have been considered within a WEF framework [116,117], most attention has focused on pairwise interactions of energy and agriculture or energy and aquaculture rather than the role of hydroelectric infrastructure as a mediator of the relationship between agriculture and agriculture [118,119].

The regulation of water flow for power generation influences downstream flow and flooding cycles, alters patterns of nutrient and sediment loading, and facilitates land subsidence and saltwater intrusion [112,113,120-124]. Although dams can benefit downstream agriculture by increasing water availability during the dry season, reduced sedimentation and salt intrusion into delta zones threaten to shift the future growth of aquaculture in favor of saltwater rather than freshwater species [119]. This would displace agriculture, in spite of efforts to adapt cropping systems to elevated levels of salinity $[110,125,126]$. Future changes that bias water use toward aquaculture would significantly influence current patterns of integration with agriculture [99,110,118,119,127-129].

Dams also reduce fish capture in the wild, which is a crucial issue $[111,130]$ that is beyond the scope of the current discussion, but it is relevant, because it limits the availability of low-quality 
captured fish for use as aquaculture feed [131]. As described below in Section 2.3, this exerts indirect effects by diverting agricultural production into feed inputs for aquaculture. The impoundment of rivers, which is especially widespread in China [132,133], consequently mediates multiple direct and indirect interactions between agriculture and aquaculture. These occur not just in delta zones, but also at Cambodia's Tonle Sap Lake, which is dependent on flood pulses from the Mekong and supports both agriculture and aquaculture [116,134-136]. Although the Mekong has been most thoroughly studied, dam-mediated tradeoffs also occur along other rivers, including the Ganges $[88,95,137]$ and the Irrawaddy $[138,139]$. Although there is also potential for agriculture-aquaculture synergies along rivers that are being harnessed for hydroelectric energy production, details have not been forthcoming [140].

\subsection{Indirect Tradeoffs between Agriculture and Aquaculture}

Localized natural resources are sufficient to sustain aquaculture under ideal circumstances [141], but in reality, aquaculture is becoming increasingly dependent on outside inputs, especially externally supplied nutrients from feed, which in many cases is imported from other countries $[18,142,143]$. Small-scale fish and shrimp ponds on farms or cooperatives may be sustainable without feed or with unprocessed feeds from nearby sources [144], but this is usually not the case for intensively managed open, partially closed, and fully closed commercial facilities, where high stocking levels and high-quality feed are required to generate economic returns [30]. The need for feed by farms and smaller facilities has even begun to outstrip local supplies in many cases [142]. Worldwide production from fish fed in aquaculture has exceeded that from those not fed for more than 20 years [18], and although more than $50 \%$ of total aquaculture now depends on feed [142], there is wide disparity by country. Slightly more than half of China's production comes from fish that are fed, but in the rest of Asia, production from fed fish exceeds that from non-fed fish by a factor of more than ten [18]. Indeed, Asia is currently the largest consumer of fish feed in the world [60].

Fish meal prepared from low value species has been a longstanding and widely used source of feed, but allowing fish to consume other fish is inherently inefficient [30]. It also disrupts aquatic food webs and potentially competes with the use of fish for direct human consumption [28,31]. Thus, aquaculture has increasingly turned to feed produced on land as an alternative, in the process generating indirect tradeoffs with agriculture that cross international boundaries and trigger environmental damage at remote locations $[15,145]$. Agriculturally supplied fish feed can be formulated from more than 20 different crop sources including soybean and corn meal, wheat and rice bran, and canola oil [146,147]. The production of these feeds is estimated by Fry et al. [31] to require about $100,000 \mathrm{~km}^{2}$ of farmland and by Waite et al. [28] to require $1 \%$ of global agricultural land. The consumption of water to produce these feeds is also substantial [31,142], and this has led to additional concern about the long-term consequences of diverting agricultural production to generate nutritional inputs for aquaculture [31,148].

In one sense, the use of land and consumption of water to produce fish and shrimp in aquaculture differs little from the exploitation of these resources to produce feed for terrestrial food animals. However, in another, it is creating questionable dependencies of aquaculture on agriculture and elevating competition for finite resources [11], even though the feed conversion efficiency for fish is much more favorable than that for terrestrial animals [149]. Possibilities to reduce such dependence include optimized feed formulations, the incorporation of agricultural by-products into feed, and polyculture, i.e., practices that involve the co-culture of several aquaculture species with different spatial and feeding niches that complement one another and minimize feed waste $[18,34,46,150]$. China, which has low dependency on feed for aquaculture, has been especially innovative in converting wastes from food, food processing, and other sources to feed [23,46,151,152] and making other refinements to reduce dependence on externally sourced nutrients [14,152].

\section{Synergies between Aquaculture and Agriculture}

Although aquaculture and agriculture are subject to real and potential tradeoffs (Section 2), powerful synergies also exist. Although a variety of terms have been coined to describe these beneficial 
interactions, all are one form or another of integrated agriculture-aquaculture (IAA). According to Prein [16], "IAA is defined as concurrent or sequential linkages between two or more aquaculture and agricultural activities were linkages may be directly on-site or indirectly off-site, satisfying needs and providing opportunities for practitioners." Thus, IAA couples agriculture to aquaculture in a positive way and firmly ties the interaction to socioeconomic benefits. Among the goals of IAA is the efficient use of water resources, so that water productivity is enhanced $[10,36,153]$.

\subsection{Rice-Fish Systems}

Rice-fish systems first appeared in China more than 1700 years ago [154] and are the most basic and by far the best known examples of IAA [34,155]. Generally of small scale, reliant on minimal external inputs, and consequently suitable for smallholders, these systems merge the footprint of fish culture with that of rice cultivation $[24,156]$. Fish can be carried into rice paddies by monsoon rains, but paddies can also be stocked with desirable species [24,36]. Rice provides shade and shelter to filter-feeding species of fish in the paddies. During the process of feeding, the fish promote nutrient cycling, consume pests, and oxygenate the soil to benefit the surrounding crop [24,28,49]. Rice yields are usually enhanced under these conditions, often substantially, and fish production serves as a bonus source of dietary protein, even though aquaculture production is modest and variable compared to that achievable in pond systems [10,24,157-159]. In parts of Cambodia, the value of fish from rice-fish systems can be as much as $80 \%$ of that from rice, delivering on average $380 \mathrm{~kg}$ of fish annually per household [160]. Synergies accrue in the form of efficient use of water and land resources.

Rice-fish systems have expanded widely across southeastern Asia [24,27,154,161,162], sometimes with significant governmental support [159], and are occasionally found in arid areas of Central Asia [163]. Nevertheless, only about $1 \%$ of rice fields are stocked with fish [164], and rice cultivation in Asia has begun to decouple from fish aquaculture in recent years [34]. This is due in large part to the comparatively high profits from conventional fish farming and the significant labor costs associated with rice-fish [24]. The introduction of high-yielding rice varieties that need less water and are best suited for monoculture also creates a technological mismatch [16] that jeopardizes these systems [24,165]. Rice-fish systems have consequently entered a phase of intensification and transition toward the production of higher value aquaculture species, including shellfish and even turtles [14].

The above examples represent the concurrent culture of aquaculture species and cultivation of rice on the same land/water footprint, but it is also possible to grow rice in seasonal rotations with aquaculture. Fish can be farmed during the season when rice is not cultivated or substituted for a crop that would otherwise be cultivated in rotation with rice. Such rotations are common in some provinces of China as well as parts of India, Bangladesh, and other countries [89,161,164,166,167]. Analogous prawn-rice and prawn-fish-rice rotations are of widespread occurrence in Bangladesh [36,168], where shrimp-rice rotations are also practiced (see Section 2.2). In Java, six different variations of rice-fish are practiced, depending on local edaphic and environmental conditions [169].

\subsection{IAA Involving Crops, Livestock, and Aquaculture}

An array of synergies in the efficient use of water and nutrient cycling can be achieved when aquaculture is integrated with both crop and animal agriculture $[16,156]$. Figure 3 diagrams the basic relationships between the components of such systems, which in the case of smallholders are usually centered on a multipurpose pond that simultaneously serves as a source of drinking water for livestock and irrigation water for crops. The pond also produces mud and residues that can be distributed onto fields as fertilizer [49,156,170-172]. Livestock wastes (manure, urine, and wasted feed) are used to fertilize crops and nourish fish in the pond, while cropping materials (grasses, rice bran, and plant residues) are used as feed for livestock and fish [10,36,49,172-174]. Synergies consequently extend in all directions.

IAA systems exist in a wide range of configurations and degrees of integration $[175,176]$ and are often employed by gardeners and smallholder farmers who have limited options 
to access nutrients [156,177,178]. Examples include Vietnam's well-established VAC integrated garden-pond-livestock system [179] and the recently described RTB system that integrates fish and roots-tubers-bananas [178]. These systems are optimized for local environmental conditions that can favor certain fish species over others or render irrigation essential or irrelevant. The crop component is variable, and a wide range of livestock — cattle, pigs, geese, ducks, and even rabbits and guinea pigs — can be accommodated [156]. Outside inputs such as inorganic fertilizers and non-farm organic nutrient sources are only rarely used as inputs [180]. Tradeoffs due to competition for land area, reduced water quantity/quality, and increased capital costs and labor demands are possible, but these can be balanced by the benefits of diversified production, increased income, and enhanced human nutrition [156].

One of the most self-contained and highly developed forms of IAA is jitang, which is an ancient Chinese mulberry-dike fish-pond system [181-183]. Jitang has been practiced for millennia, especially in the Pearl River delta, where it has largely supplanted fishing and the traditional cultivation of crops [184-186]. Over time and in response to the flood-prone nature of their environment, farmers learned to excavate soil to create ponds and use it to construct a network of raised dikes to control water flow and permit the cultivation of crops. The jitang form of IAA is characterized by the tight coupling of aquaculture, which relies on carp polycultures for efficiency, and agriculture, which is unusually flexible and accommodates both annual and perennial species [182]. Jitang is distinguished by the cultivation of mulberries, which supports a local silkworm industry that generates residues reusable as nutrient inputs; similar benefits are provided by mushroom cultivation, which utilizes nutrients from pond sediments and contributes wastes that serve as fertilizer for crops (Figure 3, dashed red lines). Although complex and continuously evolving as social and economic systems change, the jitang form of IAA is little known outside of Asia and in need of analysis from a broad perspective [182,187].

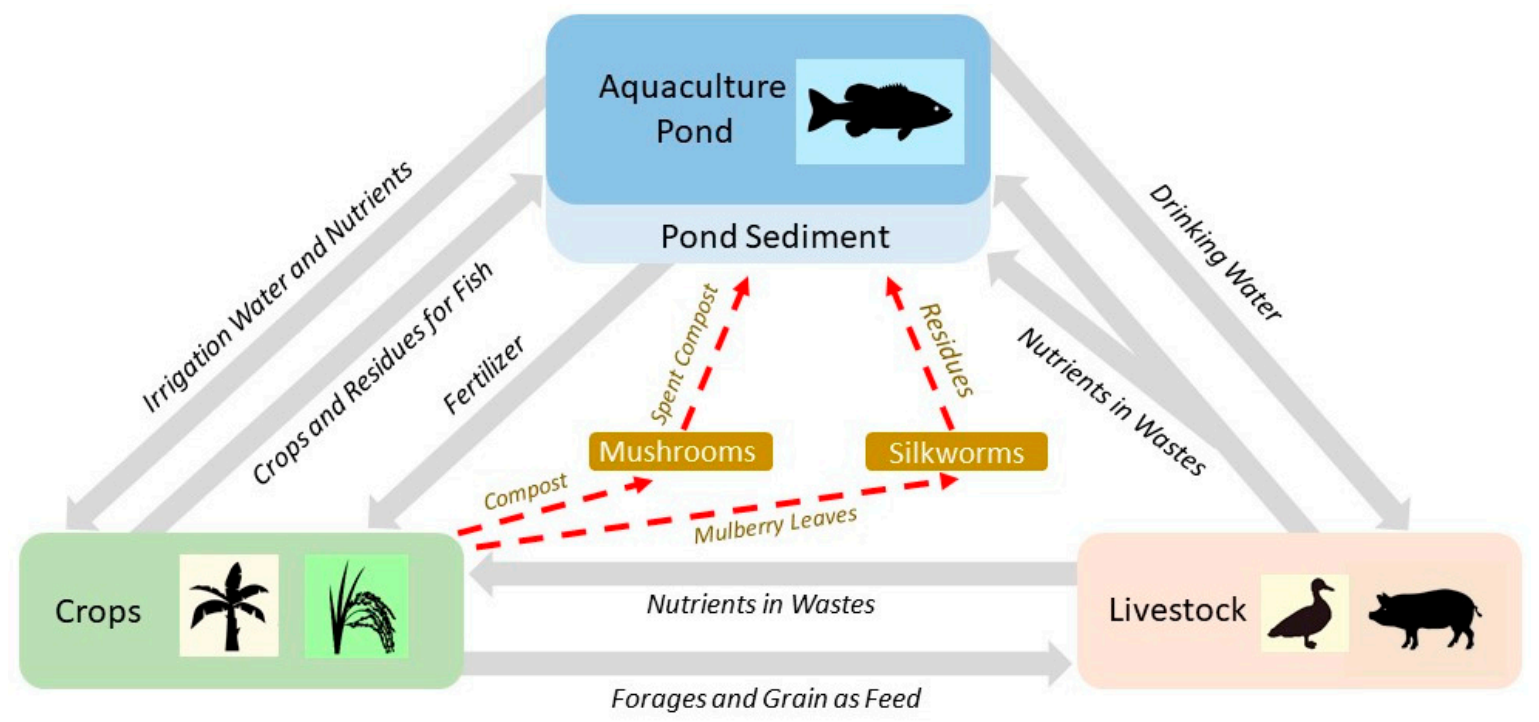

Figure 3. Schematic diagram of nutrient flows in integrated agriculture-aquaculture (IAA) systems involving fish, crops, and terrestrial farm animals. The flows of the generic system are depicted with gray arrows. Additional flows characteristic of the jitang system are indicated with dashed red arrows. For more detailed diagrammatic representations, see [156] and [182].

\subsection{IAA in Arid Asia}

Interactions of any sort between agriculture and aquaculture would seem to be improbable in Asia's arid zones, which include large areas of western China and the five post-Soviet republics of Central Asia (Kazakhstan, Kyrgyzstan, Tajikistan, Turkmenistan, and Uzbekistan). Land is plentiful and water limiting in these areas, where herding has a lengthy history, but dryland cropping is rare [188-190]. Irrigated agriculture consequently occupies some of Central Asia's best land and 
consumes $85 \%$ of the region's water, which is typically stored in artificial reservoirs and delivered to fields through interconnected networks of open ditches and canals [8,188,191,192]. Unutilized drainage water, which contains residual nutrients and elevated levels of salts, is either returned to natural waterways or collected in shallow lakes and other storage bodies $[188,193]$. The availability of irrigation water flowing into and out of cropping areas has ushered in multiple, as yet underexploited opportunities to introduce aquaculture and IAA practices [188,194-196].

Aquaculture is uncommon in arid China [101,197], but it has gained a foothold in Central Asia $[198,199]$, where it was initially promoted to compensate for the decline of capture fisheries associated with water diversion through a series of massive, Soviet era irrigation projects, the best known of which has reduced the Aral Sea to just $10 \%$ of its previous volume [200,201]. Although cage aquaculture is practiced to a limited extent, mostly in reservoirs [199,202], several variations of semi-closed aquaculture have developed to take advantage of irrigation water and thus represent forms of IAA. One approach involves stocking irrigation canals with various fish species, primarily grass-feeding carp that are useful for keeping the canals free of vegetation [188]. Fish do not consume water or appreciably affect its quality, and so the relationship between this form of aquaculture and irrigated desert agriculture is analogous to the aforementioned rice-fish systems, but at a larger scale and with spatial differences, i.e., the fish live in waterways feeding agricultural fields and not within them. Another form of IAA relies on ponds near irrigated agricultural areas (and occasionally desert oases) that have access to either fresh water or drainage water of a quality sufficient to support the culture of fish $[188,192]$. Polycultures of carp that can be fed grass and agricultural by-products have been traditionally reared in such ponds $[200,203]$, which are also sometimes supplied lime and fertilizer to encourage the growth of vegetation.

Fish ponds flourished during the Soviet period, with strong coordination and support from the central government, but aquaculture suffered serious setbacks following the independence of the five Central Asian republics in 1991 [202]. None of the new nations prioritized agriculture or aquaculture, and so irrigation infrastructure fell into disrepair, and many fish farms were forced to close. The situation has recovered somewhat in recent years [204], but longstanding challenges persist. Chief among them is the priority assigned to water usage for agriculture, which subordinates the needs of aquaculture $[200,205]$. Thus, although water resources capable of being shared are plentiful, amounting to 20-25 $\mathrm{km}^{3}$ annually in just Uzbekistan [200], water levels in reservoirs and irrigation canals fluctuate rapidly and unpredictably during the growing season, when water is drawn down for crops. Levels of salinity, sediments, and agricultural residues can also be high enough in drainage water to interfere with fish culture [188]. Although these factors tend to undermine IAA in Central Asia $[188,200,206]$, efforts are continuing to realize the potential of synergistic aquaculture-agriculture systems in this arid, food-insecure area [207-211].

\section{Perspectives}

Although often treated in isolation, agriculture and aquaculture have much in common: both have the production of food as their primary objective, are co-dependent on water and land as shared resources, and seek to function in harmony with the environment. There is growing awareness that agriculture and aquaculture are sub-components of a single system deserving of consideration from an integrated perspective [15,16,101,212-214]. Figure 4 represents a simplified diagram of such a unified system. The relative positions of the categories represented by colored ovals is subjective, of course, and the range of variability that can exist within individual categories [175] is absent. Nevertheless, the map provides an initial framework to visualize important, often overlooked relationships. Any effort at system-wide integration to reduce tradeoffs and enhance synergies among these relationships immediately confronts a spectrum of real world policy, socioeconomic, and technical issues $[156,179]$. These issues are inseparable and usually spatially explicit. Temporal factors and considerations of scale and scope also figure prominently into any consideration of integration. 
Policy has too often favored agriculture over aquaculture, especially for access to water. This bias, which occurs in both water-abundant $[60,215]$ and water-scarce regions $[200,216-218]$, reinforces the shortsighted view that aquaculture is an isolated, subordinate sector $[103,141,219,220]$ and has contributed to actions that curb and even reverse the development of aquaculture in shared waters $[52,54,61]$. The absence of policies supportive of aquaculture characterize much of arid Asia [198,199], and this, too, has constrained the development of IAA in irrigation waters [194,221,222]. Other facets of policy, especially energy policies that promote hydropower development, create externalities that affect both agriculture and aquaculture $[112,115,223]$. By altering sedimentation and flows, they can also disrupt the relationship between the two, often to benefit aquaculture $[110,112,123,124,126,127]$. Therefore, policy functions as a tool—sometimes deliberate, sometimes unintentional—for adjustment of the balance between agriculture and aquaculture.

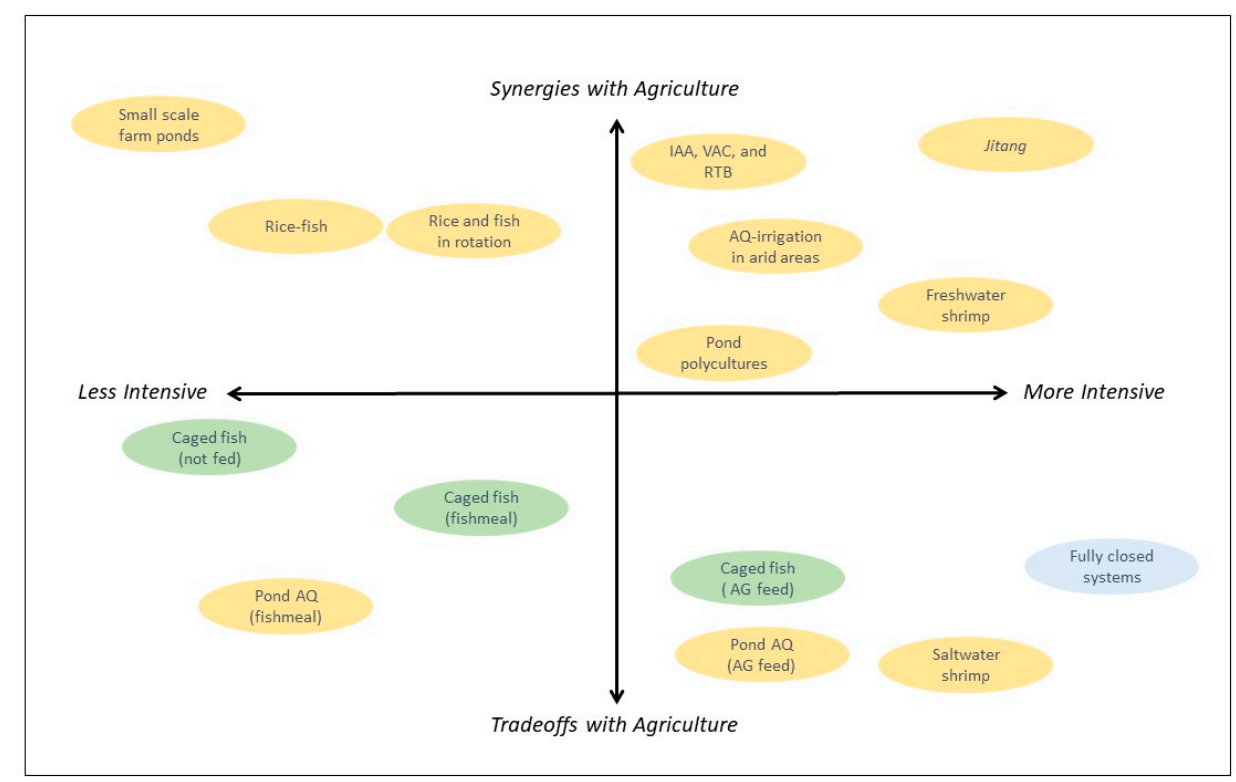

Figure 4. Quadrant analysis of synergies and tradeoffs between agriculture and various forms of aquaculture (y-axis) verses intensiveness of the aquaculture practices (x-axis). Aquaculture categories are color-coded as open (green), partially closed (orange), and closed (blue). Abbreviations are: AG, agriculture; AQ, aquaculture; IAA, integrated agriculture-aquaculture; VAC, Vietnamese garden-pond-livestock; RTB, roots-tubers-bananas.

Although the socioeconomic aspects of agriculture-aquaculture-water relationships are sometimes neglected and often under-appreciated $[89,224,225]$, they are at the heart of debates about the potential of aquaculture to help agriculture address poverty issues in rural areas [13,39,72,226-229]. As illustrated by the growth of shrimp farming, opportunities for small farmers to benefit economically from aquaculture can lead to practices that render soils unfit for growing crops [91,96-98,220]. Thus, the damage to agriculture can be permanent, even though the economic benefits of aquaculture may be short lived. Moreover, the intensification of aquaculture tends to marginalize poorer farmers, who have limited access to capital and other resources, in the process decoupling the potential benefits of aquaculture from those of agriculture.

Intensification and reliance on technology (Figure 4), including biotechnology [230-232], can nevertheless increase food productivity per unit of area and unit of water consumption while simultaneously generating other efficiencies [215], i.e., alleviating the need for scarce labor in small-scale IAA systems [156]. However, technology and intensification can also create new tradeoffs by promoting crop monocultures and continuous aquaculture or rendering aquaculture dependent on agricultural feeds $[15,233]$. It has also been noted that water problems tend to persist in spite of new 
technologies $[3,234]$, which in the case of irrigation in arid areas, often simply facilitate the expansion of agriculture rather than the conservation of water [235-238].

The dynamics among the above factors highlight three issues that will undoubtedly define how future interrelationships between agriculture and aquaculture evolve. The first is a realization that although the current geographical intersection of agriculture and aquaculture is Asia, this will shift and significantly expand in the future as the latter gains a firmer foothold in other parts of the world. This is already occurring [18,221,239]. Second, the heterogeneity and variability of Water, Agriculture, and Aquaculture will command more attention as the effects of climate change spread and intensify [10,240-243]. Factors such as the scope and scale of production, spatiotemporal relationships, dependence on transboundary waters, adjustment to changes brought on by large-scale hydraulic infrastructure, and competition with other users for increasingly scarce water will all assume increasing importance. The livestock component, which has undergone less quantitative analysis than crop-based agriculture —in part because it is less amenable to analysis by remote sensing [244] —warrants more attention with respect to all of these issues.

Finally, there is a need for additional studies to identify the best methods to assess beneficial and detrimental relationships between agriculture and aquaculture as mediated by water. Figure 4 maps such relationships, but how can they best be measured, modeled, analyzed, and evaluated? We have focused here on commonly employed measures such as land and water footprints, soil and water quality, and food production. Nevertheless, others are available: food output as calories, protein, or other components of human nutrition; contributions to food security or to the national economy; achievement of desired socioeconomic goals; alleviation of poverty; and contribution to environmental sustainability $[13,15,82,245-247]$. Each warrants further assessment in future considerations of Water, Agriculture, and Aquaculture.

Author Contributions: S.G.P. conducted the literature review and drafted the manuscript. S.N. and W.O. edited the draft and provided additional information, local insights, and supplementary references. All authors have read and agreed to the published version of the manuscript.

Funding: The authors wish to express their gratitude to the Nanjing Agricultural University-Michigan State University Asia Hub Program (grant number 2017-AH-10 awarded to W.O. and S.G.P.) for funding the collaboration that generated this paper.

Acknowledgments: We thank J. Qi and our other colleagues from the Nanjing Agricultural University-Michigan State University Asia Hub for their encouragement and support during preparation of the manuscript.

Conflicts of Interest: The authors declare no conflict of interest.

\section{References}

1. Steffen, W.; Richardson, K.; Rockström, J.; Cornell, S.E.; Fetzer, I.; Bennett, E.M.; Biggs, R.; Carpenter, S.R.; de Varies, W.; de Wit, C.A.; et al. Planetary boundaries: Guiding human development on a changing planet. Science 2015, 347, 1259855. [CrossRef] [PubMed]

2. Do Rosário Cameira, M.; Pereira, S. Innovation issues in water, agriculture and food. Water 2019, 11, 1230. [CrossRef]

3. D’Odorico, P.; Davis, K.F.; Rosa, L.; Carr, J.A.; Chiarelli, D.; Dell'Angelo, J.; Gephart, J.; MacDonald, G.K.; Seekell, D.A.; Suweis, S.; et al. The global food-energy-water nexus. Rev. Geophys. 2018, 56, 456-531. [CrossRef]

4. Albrecht, T.R.; Crootof, A.; Scott, C.A. The water-energy-food nexus: A systematic review of methods for nexus assessment. Environ. Res. Lett. 2018, 13, 043002. [CrossRef]

5. Simpson, G.B.; Jewitt, G.P.W. The water-energy-food nexus in the Anthropocene: Moving from 'nexus thinking' to 'nexus action. Curr. Opin. Environ. Sust. 2019, 40, 117-123. [CrossRef]

6. Geressu, R.; Siderius, C.; Harou, J.J.; Kashaigili, J.; Pettinotti, L.; Conway, D. Assessing river basin development given water-energy-food-environment interdependencies. Earth's Future 2020, 7, e2019EF001464. [CrossRef]

7. Harvey, M.; Pilgrim, S. The new competition for land: Food, energy, and climate change. Food Policy 2011, 36, S40-S51. [CrossRef] 
8. Duan, W.; Chen, Y.; Zou, S.; Nover, D. Managing the water-climate-food nexus for sustainable development in Turkmenistan. J. Clean. Prod. 2019, 220, 212-224. [CrossRef]

9. Laspidou, C.S.; Mellios, N.; Kofinas, D. Towards ranking the water-energy-food-land use-climate nexus interlinkages for building a nexus conceptual model with a heuristic algorithm. Water 2019, 11, 306. [CrossRef]

10. Ahmed, N.; Thompson, S.; Glaser, M. Global aquaculture productivity, environmental sustainability, and climate change adaptability. Environ. Manag. 2019, 63, 159-172. [CrossRef]

11. Troell, M.; Naylor, R.L.; Metian, M.; Beveridge, M.; Tyedmers, P.H.; Folke, C.; Arrow, K.J.; Barrett, S.; Crepin, A.-S.; Ehrlich, P.R.; et al. Does aquaculture add resilience to the global food system? Proc. Nat. Acad. Sci. USA 2014, 111, 13257-13263. [CrossRef] [PubMed]

12. Béné, C.; Barange, M.; Subasinghe, R.; Pinstrup-Andersen, P.; Merino, G.; Hemre, G.-I.; Williams, M. Feeding 9 billion by 2050 - Putting fish back on the menu. Food Secur. 2015, 7, 261-274. [CrossRef]

13. Béné, C.; Arthur, R.; Norbury, H.; Allison, E.H.; Beveridge, M.; Bush, S.R.; Campling, L.; Leschen, W.; Little, D.; Squires, D.; et al. Contribution of fisheries and aquaculture to food security and poverty reduction: Assessing the current evidence. World Devel. 2016, 79, 177-196. [CrossRef]

14. Wang, Q.; Zhongjie, L.; Gui, J.; Liu, J.; Ye, S.; Yuan, J.; De Silva, S.S. Paradigm changes in freshwater aquaculture practices in China: Moving towards achieving environmental integrity and sustainability. AMBIO 2018, 47, 410-426. [CrossRef]

15. Blanchard, J.L.; Watson, R.A.; Fulton, E.A.; Cottrell, R.S.; Nash, K.L.; Bryndum-Buchholz, A.; Büchner, M.; Carozza, D.A.; Cheung, W.W.; Elliott, J.; et al. Linked sustainability challenges and trade-offs among fisheries, aquaculture and agriculture. Nat. Ecol. Evol. 2017, 1, 1240-1249. [CrossRef] [PubMed]

16. Prein, M. Integration of aquaculture into crop-animal systems in Asia. Agric. Syst. 2002, 71, 127-146. [CrossRef]

17. Pretty, J. Agricultural sustainability: Concepts, principles and evidence. Phil. Trans. R. Soc. B. 2007, 363, 447-465. [CrossRef]

18. FAO. State of World Fisheries and Aquaculture; United Nations Food and Agricultural Organization: Rome, Italy, 2020.

19. Garlock, T.; Asche, F.; Anderson, J.; Bjørndal, T.; Kumar, G.; Lorenzen, K.; Ropicki, A.; Smith, M.D.; Tveterås, R. A global blue revolution: Aquaculture growth across regions, species, and countries. Rev. Fish. Sci. Aquacult. 2020, 28, 107-116. [CrossRef]

20. Lev-Yadun, S.; Gopher, A.; Abbo, S. The cradle of agriculture. Science 2000, 288, 1602-1603. [CrossRef]

21. Leff, B.; Ramankutty, N.; Foley, J.A. Geographic distribution of major crops across the world. Glob. Biogeochem. Cycles 2004, 18, GB1009. [CrossRef]

22. Marie, P. The Evolution of Agricultural Productivity; Brittanica Educational Publishing: New York, NY, USA, 2019.

23. Jia, J.; Miao, W.; Cai, J.; Yuan, X. Contribution of Chinese agriculture to the sector, globally, and to overall food security. In Aquaculture in China: Success Stories and Modern Trends, 1st ed.; Gui, J.-F., Tang, Q., Li, Z., Liu, J., De Silva, S.S., Eds.; John Wiley and Sons: Hoboken, NJ, USA, 2018; pp. 3-24.

24. Lu, J.; Li, X. Review of rice-fish-farming systems in China-One of the Globally Important Ingenious Agricultural Heritage Systems (GIAHS). Aquaculture 2006, 260, 106-113. [CrossRef]

25. Harland, J. The origins of aquaculture. Nat. Ecol. Evol. 2019, 3, 1378-1379. [CrossRef] [PubMed]

26. Diana, J.S.; Egna, H.S.; Chopin, T.; Peterson, M.S.; Cao, L.; Pomeroy, R.; Verdegem, M.; Slack, W.T.; Bondad-Reantaso, M.G.; Cabello, F. Responsible aquaculture in 2050: Valuing local conditions and human innovations will be key to success. BioScience 2013, 4, 255-262. [CrossRef]

27. Edwards, P. Traditional Asian aquaculture. In New Technologies in Aquaculture, Improving Production, Efficiency, Quantity and Environmental Management; Burnell, G., Allan, G., Eds.; Woodhead Publishing: Oxford, UK, 2009; pp. 1029-1063.

28. Waite, R.; Beveridge, M.; Brummett, R.; Castine, S.; Chaiyawannakarn, N.; Kaushik, S.; Munkung, R.; Nawapakpilai, S.; Phillips, M. Improving Productivity and Environmental Performance of Aquaculture; World Resources Institute: Washington, DC, USA, 2014.

29. Little, D.C.; Newton, R.W.; Beveridge, M.C.M. Aquaculture: A rapidly growing and significant source of sustainable food? Status, transitions and potential. Proc. Nutr. Soc. 2016, 75, 274-286. [CrossRef] 
30. Naylor, R.L.; Goldburg, R.J.; Primavera, J.H.; Kautsky, N.; Beveridge, M.C.M.; Clay, J.; Folke, C.; Lubchenco, J.; Mooney, H.; Troell, M. Effect of aquaculture on world fish supplies. Nature 2000, 405, 1017-1024. [CrossRef]

31. Fry, J.P.; Love, D.C.; Macdonald, G.K.; West, P.C.; Engstrom, P.M.; Nachman, K.E.; Lawrence, R.S. Environmental health impacts of feeding crops to farmed fish. Environ. Int. 2016, 91, 201-214. [CrossRef]

32. Tidwell, J.H. Characteristics and categories of aquaculture production systems. In Aquaculture Production Systems; Tidwell, J.H., Ed.; John Wiley \& Sons: Oxford, UK, 2012; pp. 64-78.

33. Kang, B.; Huang, X.; Li, J.; Liu, M.; Guo, L.; Han, C.-C. Inland fisheries in China: Past, present, and future. Rev. Fish. Sci. Aquacult. 2017, 25, 270-285. [CrossRef]

34. Edwards, P. Aquaculture environment interactions: Past, present and likely future trends. Aquaculture 2015, 447, 2-14. [CrossRef]

35. Costa-Pierce, B. Environmental impacts of nutrients from aquaculture: Towards the evolution of sustainable aquaculture systems. In Aquaculture and Water Resource Management; Baird, D.J., Beveridge, M.C.M., Kelly, L.A., Eds.; Blackwell Science Ltd.: Oxford, UK, 1996; pp. 81-113.

36. Ahmed, N.; Ward, J.D.; Saint, C.P. Can integrated aquaculture-agriculture (IAA) produce "more crop per drop"? Food Secur. 2014, 6, 767-779. [CrossRef]

37. Tacon, A.G.J.; Halwart, M. Cage aquaculture: A global overview. In FAO Fisheries Technical Paper No. 498, Cage Aquaculture-Regional Reviews and Global Overview; Halwart, M., Soto, D., Arthur, J.R., Eds.; United Nations Food and Agriculture Organization: Rome, Italy, 2007; pp. 1-16.

38. Klinger, D.; Naylor, R. Searching for solutions in aquaculture; Charting a sustainable course. Annu. Rev. Environ. Resourc. 2012, 37, 247-276. [CrossRef]

39. Belton, B.; Little, D.C. Immanent and interventionist inland Asian aquaculture development and its outcomes. Devel. Policy Rev. 2011, 29, 459-484. [CrossRef]

40. Liu, J.; Wang, Q.; Zhang, T.; Ye, S.; Li, W.; Yuan, J.; Zhongjie, L. Development of lake and reservoir aquaculture related practices in China. In Aquaculture in China: Success Stories and Modern Trends, 1st ed.; Gui, J.-F., Tang, Q., Li, Z., Liu, J., De Silva, S.S., Eds.; John Wiley and Sons: Hoboken, NJ, USA, 2018; pp. 599-610.

41. Guo, L.; Li, Z. Effects of nitrogen and phosphorus from fish cage-culture on the communities of a shallow lake in middle Yangtze River basin of China. Aquaculture 2003, 226, 201-212. [CrossRef]

42. Bouwman, A.F.; Beusen, A.H.W.; Overbeek, C.C.; Bureau, D.P.; Pawlowski, M.; Glibert, P.M. Hindcasts and future projections of global inland and coastal nitrogen and phosphorus loads due to finfish aquaculture. Rev. Fish. Sci. 2013, 21, 112-156. [CrossRef]

43. Cai, C.-F.; Gu, X.; Ye, Y.; Yang, C.; Dai, X.; Chen, N.; Yang, C. Assessment of pollutant loads discharged from aquaculture ponds around Taihu Lake, China. Aquacult. Res. 2012, 44, 795-806. [CrossRef]

44. Ottinger, M.; Clauss, K.; Kuenzer, C. Aquaculture: Relevance, distribution, impacts and spatial assessments-A review. Ocean. Coast. Manag. 2016, 119, 244-266. [CrossRef]

45. Martinez-Porchas, M.; Martinez-Cordova, L.R. World aquaculture: Environmental impacts and troubleshooting alternatives. Sci. World J. 2012, 2012, 389623. [CrossRef]

46. Sharpley, A.N.; Chapra, S.C.; Wedepohl, R.; Sims, J.T.; Daniel, T.C.; Reddy, K.R. Managing agricultural phosphorus for protection of surface waters: Issues and options. J. Environ. Qual. 1994, 23, 437-451. [CrossRef]

47. Xia, Y.; Zhang, M.; Tsang, D.C.W.; Geng, N.; Lu, D.; Zhu, L.; Igalavithana, A.D.; Dissanayake, P.D.; Rinklebe, J.; Yang, X.; et al. Recent advances in control technologies for non-point source pollution with nitrogen and phosphorus from agricultural runoff: Current practices and future prospects. Appl. Biol. Chem. 2020, 63, 8. [CrossRef]

48. Lebel, L.; Lebel, P.; Chuah, C.J. Water use by inland aquaculture in Thailand: Stakeholder perceptions, scientific evidence, and public policy. Environ. Manag. 2019, 63, 554-563. [CrossRef]

49. Heneres, M.N.P.; Medeiros, M.V.; Camargo, A.F.M. Overview of strategies that contribute to the environmental sustainability of pond aquaculture: Rearing systems, residue treatment, and environmental assessment tools. Rev. Aquacult. 2019, 12, 453-470. [CrossRef]

50. Valenti, W.C.; Kimpara, J.M.; de, L.; Preto, B.; Moraes-Valenti, P. Indicators of sustainability to assess aquaculture systems. Ecol. Indic. 2018, 88, 402-413. [CrossRef]

51. Ma, T.; Zhao, N.; Ni, Y.; Yi, J.; Wilson, J.P.; He, L.; Du, Y.; Pei, T.; Zhou, C.; Song, C.; et al. China's improving inland surface water quality since 2003. Sci. Adv. 2020, 6, eaau3798. [CrossRef] [PubMed] 
52. Qin, B.; Zhu, G.; Gao, G.; Zhang, Y.; Li, W.; Paerl, H.W.; Carmichael, W.W. A drinking water crisis in Lake Taihu, China: Linkage to climatic variability and lake management. Environ. Manag. 2010, 45, 105-112. [CrossRef] [PubMed]

53. Xu, P.; Qin, B.; Horst, B.; Huang, W. Nitrogen surplus of upstream agriculture land of Lake Taihu and eutrophication impact. J. Lake Sci. 2006, 18, 395-400. (In Chinese)

54. Wang, M.; Strokal, M.; Burek, P.; Kroeze, C. Excess nutrient loads to Lake Taihu: Opportunities for nutrient reduction. Sci. Total Environ. 2019, 664, 865-873. [CrossRef]

55. Pueppke, S.G.; Zhang, W.; Li, H.; Chen, D.; Ou, W. An integrative framework to control nutrient loss: Insights from two hilly basins in China's Yangtze River delta. Water 2019, 11, 2036. [CrossRef]

56. Li, Z.; Liu, J.; Wang, Q.; De Silva, S.S. Inland aquaculture: Trends and prospects. In Aquaculture in China: Success Stories and Modern Trends, 1st ed.; Gui, J.-F., Tang, Q., Li, Z., Liu, J., De Silva, S.S., Eds.; John Wiley and Sons: Hoboken, NJ, USA, 2018; pp. 25-37.

57. MOA. Zero Growth in Synthetic Fertilizer Use from 2020 Onwards; Ministry of Agriculture of the People's Republic of China: Beijing, China, 2015. (In Chinese)

58. Xu, X.; Tan, Y.; Yang, L.; Fu, B.; Gao, G. Redlines for the greening of China. Environ. Sci. Policy 2018, 79, 447-451. [CrossRef]

59. Delang, C.O.; Yuan, Z. China's Grain for Green Program; Springer: Cham, Switzerland, 2015; pp. 1-213.

60. Subasinghe, R. FAO Fisheries and Aquaculture Circular No. 1135/5, Regional Review on Status and Trends in Aquaculture Development in Asia-2015; United Nations Food and Agricultural Organization: Rome, Italy, 2017.

61. Meng, Y.; Du, P.; Wang, X.; Bai, X.; Guo, S. Monitoring human-induced surface water disturbance around Taihu Lake since 1984 by time series Landsat images. IEEE J. Sel. Top. Appl. Earth Obs. Remote Sens. 2020, 13, 3780-3789. [CrossRef]

62. Guangwei, Z.; Weimin, C.; Hengpeng, L.; Li, R.; Zhao, G.; Linlin, Z.; Yongxia, G.; Ran-Ran, H.; Yunlin, Z.; Yang, C. Response of water quality to the catchment development and protection in Tianmuhu Reservoir, China. J. Lake Sci. 2013, 25, 809-817. (In Chinese) [CrossRef]

63. Zhu, G.; Cui, Y.; Han, X.; Li, H.; Zhu, M.; Deng, J.; Li, H.; Chen, W. Response of phytoplankton to nutrient reduction in Shahe Reservoir, Taihu catchment, China. J. Freshw. Ecol. 2015, 30, 41-58. [CrossRef]

64. Guo, Z.; Li, Z.; Liu, J.; Zhu, F.; Perera, H.A.C.C. Status of reservoir fisheries in China and their effect on environment. In Tropical and Sub-Tropical Reservoir Limnology in China; Han, B.-P., Liu, Z., Eds.; Springer: Dordrecht, The Netherlands, 2012; pp. 259-276.

65. Mims, S.D. Paddlefish: International status. In Paddlefish Aquaculture; Mims, S.D., Shelton, W.L., Eds.; John Wiley \& Sons: Hoboken, NJ, USA, 2015; pp. 153-178.

66. Dai, Y.; Feng, L.; Hou, X.; Choi, C.-Y. Policy-driven changes in enclosure fisheries of large lakes in the Yangtze plain: Evidence from satellite imagery. Sci. Total Environ. 2020, 688, 1286-1297. [CrossRef]

67. Rai, R.; Zhang, Y.; Paudel, B.; Li, S.; Khanal, N.R. A synthesis of studies on land use and land cover dynamics during 1930-2015 in Bangladesh. Sustainability 2017, 9, 1866. [CrossRef]

68. Primavera, J.H. Overcoming the impacts of aquaculture on the coastal zone. Ocean. Coastal Manag. 2006, 49, 531-545. [CrossRef]

69. Belton, B.; Hein, A.; Htoo, K.; Kham, L.S. MSU International Development Working Paper 140, Aquaculture in Transition: Value Chain Transformation, Fish. and Food Security in Myanmar; Michigan State University: East Lansing, MI, USA, 2015.

70. Flaherty, M.; Szuster, B.; Miller, P. Low salinity inland shrimp farming in Thailand. AMBIO 2000, 29, 174-179. [CrossRef]

71. Ahmed, N.; Thompson, S. The blue dimensions of aquaculture: A global synthesis. Sci. Total Environ. 2019, 652, 851-861. [CrossRef] [PubMed]

72. Filipski, M.; Belton, B. Give a man a fishpond: Modeling the impacts of aquaculture in the rural economy. World Devel. 2018, 110, 205-223. [CrossRef]

73. De Silva, S.S. Aquaculture: A newly emergent food production sector-And perspectives of its impacts on biodiversity and conservation. Biodivers. Conserv. 2012, 21, 3187-3220. [CrossRef]

74. Cheng, L.; Brown, G.; Liu, Y.; Searle, G. An evaluation of contemporary China's land use policy-The Link Policy: A case study from Ezhou, Hubei Province. Land Use Policy 2020, 91, 104423. [CrossRef]

75. Yang, H.; Li, X. Cultivated land and food supply in China. Land Use Policy 2000, 17, 73-88. [CrossRef] 
76. Fang, J.; Rao, S.; Zhao, S. Human-induced long-term changes in the lakes of the Jianghan plain, central Yangtze. Front. Ecol. Environ. 2005, 23, 186-192. [CrossRef]

77. Tao, S.; Fang, J.; Ma, S.; Cai, Q.; Xiong, X.; Tian, D.; Zhao, X.; Fang, L.; Zhang, H.; Zhu, J.; et al. Changes in China's lakes: Climate and human impacts. Nat. Sci. Rev. 2020, 7, 132-140. [CrossRef]

78. Zhao, S.; Fang, J.; Ji, W.; Tang, Z. Lake restoration from impoldering: Impact of land conversion on riparian landscape in Honghu Lake area, central Yangtze. Agric. Ecosyst. Environ. 2003, 95, 111-118. [CrossRef]

79. Yan, G. Fisheries development in Xinjiang, China. In FAO Fisheries Technical Paper No. 430, Fisheries in Irrigation Systems in Arid Asia; Petr, T., Ed.; United Nations Food and Agricultural Organization: Rome, Italy, 2003; pp. 95-100.

80. Lebel, L.; Lebel, P.; Chuah, C.J. Governance of aquaculture water use. Int. J. Water Res. Devel. 2018, 35, 659-681. [CrossRef]

81. Truong, T.D.; Do, L.H. Mangrove forests and aquaculture in the Mekong river delta. Land Use Policy 2018, 73, 20-28. [CrossRef]

82. Ahmed, M.; Lorica, M.H. Improving developing country food security through aquaculture development-Lessons from Asia. Food Policy 2002, 27, 125-141. [CrossRef]

83. Braaten, R.O.; Flaherty, M. Hydrology of inland brackishwater shrimp ponds in Chachoengsao, Thailand. Aquacult. Eng. 2000, 23, 295-313. [CrossRef]

84. Poapongsakorn, N.; Ruhs, M.; Tangjitwisuth, S. Problems and outlook of agriculture in Thailand. Tdri Quart. Rev. 1998, 13, 3-14.

85. Vandergeest, P.; Flaherty, M.; Miller, P. A political ecology of shrimp aquaculture in Thailand. Rural Soc. 2009, 64, 573-596. [CrossRef]

86. Flaherty, M.; Vandergeest, P.; Miller, P. Rice paddy or shrimp pond: Tough decisions in rural Thailand. World Devel. 1999, 27, 2045-2060. [CrossRef]

87. Shankar, B.; Halls, A.; Barr, J. Rice versus fish revisited: On the integrated management of floodplain resources in Bangladesh. Nat. Res. Forum 2004, 28, 91-101. [CrossRef]

88. Azad, A.K.; Jensen, K.R.; Lin, C.K. Coastal aquaculture development in Bangladesh: Unsustainable and sustainable experiences. Environ. Manag. 2009, 44, 800-809. [CrossRef]

89. Islam, M.R.; Tabeta, S. Shrimp vs prawn-rice farming in Bangladesh: A comparative impacts study on local environments and livelihoods. Ocean. Coast. Manag. 2019, 168, 167-176. [CrossRef]

90. Islam, M.S.; Milstein, A.; Wahab, M.A.; Kamal, A.H.M.; Dewan, S. Production and economic return of shrimp aquaculture in coastal ponds of different sizes and with different management regimes. Aquacult. Int. 2005, 13, 489-500. [CrossRef]

91. Morshed, M.M.; Islam, M.S.; Lohano, H.D.; Shyamsundar, P. Production externalities of shrimp aquaculture on paddy farming in coastal Bangladesh. Agric. Water Manag. 2020, 238, 106213. [CrossRef]

92. Parvin, G.A.; Ali, H.; Fujita, K.; Abedin, A.; Habiba, U.; Shaw, R. Land use change in southwestern coastal Bangladesh: Consequence to food and water supply. In Land Use Management in Disaster Risk Reduction; Banba, M., Shaw, R., Eds.; Springer: Tokyo, Japan, 2017; pp. 381-401.

93. Bernier, Q.; Sultana, P.; Bell, A.R.; Ringler, C. Water management and livelihood choices in southwestern Bangladesh. J. Rural Stud. 2016, 45, 134-145. [CrossRef]

94. Paul, B.G.; Vogl, C.R. Impacts of shrimp farming in Bangladesh: Challenges and alternatives. Ocean. Coast. Manag. 2011, 54, 201-211. [CrossRef]

95. Ito, S. From rice to prawns: Economic transformation and agrarian structure in rural Bangladesh. J. Peasant Stud. 2002, 29, 47-70. [CrossRef]

96. Chowdhury, M.A.; Shivakoti, G.P.; Salaquzzaman, M. A conceptual framework for the sustainability assessment procedures of the shrimp aquaculture industry in coastal Bangladesh. Int. J. Agric. Resour. Gov. Ecol. 2006, 5, 162-184. [CrossRef]

97. Karim, M.R. Present status and strategies for future development of shrimp farming in Bangladesh. In Environmental and Socio-Economic Impacts of Shrimp-Farming in Bangladesh; Wahab, M.A., Ed.; BARC Centre: Dhaka, Bangladesh, 2003; pp. 1-8.

98. Wahab, M.A. Environmental impacts of shrimp farming in the coastal areas of Bangladesh. In Environmental and Socio-economic Impacts of Shrimp-farming in Bangladesh; Wahab, M.A., Ed.; BARC Centre: Dhaka, Bangladesh, 2003; pp. 19-32. 
99. Kruse, J.; Koch, M.; Khoi, C.M.; Braun, G.; Sebesvari, Z.; Amelung, W. Land use change from permanent rice to alternating rice-shrimp or permanent shrimp in the coastal Mekong Delta, Vietnam: Changes in the nutrient status and binding forms. Sci. Total Environ. 2020, 703, 134758. [CrossRef]

100. Tho, N.; Vromant, N.; Hung, N.T.; Hens, L. Soil salinity and sodicity in a shrimp farming coastal area on the Mekong Delta, Vietnam. Environ. Geol. 2008, 54, 1739-1746. [CrossRef]

101. Gephart, J.A.; Troell, M.; Henriksson, P.J.G.; Beveridge, M.C.; Verdegem, M.; Metian, M.; Mateos, L.D.; Deutsch, L. The 'seafood gap' in the food-water nexus literature-Issues surrounding freshwater use in seafood production chains. Adv. Water Resourc. 2017, 110, 505-514. [CrossRef]

102. Lázár, A.N.; Clarke, D.; Adams, H.; Akanda, A.R.; Szabo, S.; Nicholls, R.J.; Matthews, Z.; Begum, D.; Saleh, A.F.M.; Abedin, A.; et al. Agricultural livelihoods in coastal Bangladesh under climate and environmental change-A model framework. Environ. Sci. Process. Impacts 2015, 17, 1018-1031. [CrossRef] [PubMed]

103. Lebel, L.; Tri, N.H.; Saengnoree, A.; Pasong, S.; Buatama, U.; Thoa, L.K. Industrial transformation and shrimp aquaculture in Thailand and Vietnam: Pathways to ecological, social, and economic sustainability? AMBIO 2002, 31, 311-323. [CrossRef] [PubMed]

104. Bell, A.R.; Bryan, E.; Ringler, C.; Ahmed, A. Rice productivity in Bangladesh: What are the benefits of irrigation? Land Use Policy 2015, 48, 1-12. [CrossRef]

105. Swapan, M.S.H.; Gavin, M. A desert in the delta: Participatory assessment of changing livelihoods induced by commercial shrimp farming in Southwest Bangladesh. Ocean. Coast. Manag. 2011, 54, 45-54. [CrossRef]

106. Dung, L.C.; Hoanh, C.T.; Le Page, C.; Bousquet, F.; Gajaseni, N. Facilitating dialogue between aquaculture and agriculture: Lessons from role-playing games with farmers in the Mekong Delta, Vietnam. Water Policy 2009, 11, 80-93. [CrossRef]

107. Páez-Osuna, F. The environmental impact of shrimp aquaculture: Causes, effects, and mitigating alternatives. Environ. Manag. 2001, 28, 131-140. [CrossRef]

108. Nguyen, V.K.; Han, N.H.; Cramb, R. Trends in rice-based farming systems in the Mekong Delta. In White Gold: The Commercialisation of Rice Farming in the Lower Mekong Basin; Cramb, R., Ed.; Palgrave Macmillan: Singapore, 2020; pp. 347-373.

109. King, P.; Bird, J.; Haas, L. The Current Status of Environmental Criteria for Hydropower Development in the Mekong Region. A Literature Compilation; Mekong River Commission: Vientiane, Laos, 2007.

110. Boretti, A. Implications on food production of the changing water cycle in the Vietnamese Mekong Delta. Glob. Ecol. Conserv. 2020, 22, e00989. [CrossRef]

111. Orr, S.; Pittock, J.; Chapagain, A.; Dumaresq, D. Dams on the Mekong River: Lost fish protein and the implications for land and water resources. Glob. Environ. Chang. 2012, 22, 925-932. [CrossRef]

112. Pokhrel, Y.N.; Burbano, M.; Roush, J.; Kang, H.; Sridhar, V.; Hyndman, D.W. A review of the integrated effects of changing climate, land use, and dams on Mekong River hydrology. Water 2018, 10, 266. [CrossRef]

113. Hecht, J.S.; Lacombe, G.; Arias, M.E.; Dang, T.D.; Piman, T. Hydropower dams of the Mekong River basin: A review of their hydrological impacts. J. Hydrol. 2019, 568, 285-300. [CrossRef]

114. Nhan, N.H.; Cao, N.B. Damming the Mekong: Impacts in Vietnam and solutions. In Coasts and Estuaries, The Future; Wolanski, E., Day, J.W., Elliott, M., Ramachandran, R., Eds.; Elsevier: Amsterdam, The Netherlands, 2019; pp. 321-340. [CrossRef]

115. Costa-Pierce, B.A. Constraints to the sustainability of cage aquaculture for resettlement from hydropower dams in Asia: An Indonesian case study. J. Environ. Devel. 1998, 7, 333-363. [CrossRef]

116. Keskinen, M.; Someth, P.; Salmivaara, A.; Kummu, M. Water-energy-food nexus in a transboundary river basin: The case of Tonle Sap Lake, Mekong River basin. Water 2015, 7, 5416-5436. [CrossRef]

117. Keskinen, M.; Guillaume, J.H.A.; Kattelus, M.; Porkka, M.; Räsänen, T.A.; Varis, O. The water-energy-food nexus and the transboundary context: Insights from large Asian rivers. Water 2016, 8, 193. [CrossRef]

118. Minderhoud, P.S.J.; Middelkoop, H.; Erkens, G.; Stouthamer, E. Groundwater extraction may drown mega-delta: Projections of extraction-induced subsidence and elevation of the Mekong delta for the 21st century. Environ. Res. Commun. 2020, 2, 011005. [CrossRef]

119. Kummu, M.; Varis, O. Sediment-related impacts due to upstream reservoir trapping, the Lower Mekong River. Geomorphology 2007, 85, 275-293. [CrossRef] 
120. Kondolf, G.M.; Schmitt, R.J.; Carling, P.A.; Darby, S.; Arias, M.; Bizzi, S.; Castelletti, A.; Cochrane, T.A.; Gibson, S.; Kummu, M.; et al. Changing sediment budget of the Mekong: Cumulative threats and management strategies for a large river basin. Sci. Total Environ. 2018, 625, 114-134. [CrossRef]

121. Kuenzer, C.; Campbell, I.C.; Roch, M.; Leinenkugel, P.; Tuan, V.Q.; Dech, S. Understanding the impact of hydropower developments in the context of upstream-downstream relations in the Mekong river basin. Sustain. Sci. 2013, 8, 565-584. [CrossRef]

122. Fan, H.; He, D.; Wang, H. Environmental consequences of damming the mainstream Lancang-Mekong River: A review. Earth-Sci. Rev. 2015, 146, 77-91. [CrossRef]

123. VMNRE. Vietnam Ministry of Natural Resources and Environment Study on the Impacts of Mainstream Hydropower on the Mekong River; HDR, Inc.: Englewood, CO, USA, 2015.

124. Yoshida, Y.; Lee, H.S.; Trung, B.H.; Tran, H.-D.; Lall, M.K.; Kakar, K.; Xuan, T.D. Impacts of mainstream hydropower dams on fisheries and agriculture in Lower Mekong Basin. Sustainability 2020, 12, 2408. [CrossRef]

125. Olson, K.R.; Morton, L.R. Polders, dikes, canals, rice, and aquaculture in the Mekong Delta. J. Soil Water Conserv. 2018, 73, 83A-89A. [CrossRef]

126. Käkönen, M. Mekong Delta at the crossroads: More control or adaptation. AMBIO 2008, 37, $205-212$. [CrossRef]

127. Fredén, F. Impacts of Dams on Lowland Agriculture in the Mekong River Catchment; Lunds Universitets Naturgeografiska Institution-Seminarieuppsatser: Lund, Sweden, 2011.

128. Reddy, I.N.B.L.; Kim, B.-K.; Yoon, I.-S.; Kim, K.-H.; Kwon, T.-R. Salt tolerance in rice: Focus on mechanisms and approaches. Rice Sci. 2017, 14, 123-144. [CrossRef]

129. Liu, S.; Li, X.; Chen, D.; Duan, Y.; Ji, H.; Zhang, L.; Chai, Q.; Hu, X. Understanding land use/land cover dynamics and impacts of human activities in the Mekong Delta over the last 40 years. Glob. Ecol. Conserv. 2020, 22, e00991. [CrossRef]

130. Pittock, J.; Dumaresq, D.; Orr, S. The Mekong River: Trading off hydropower, fish, and food. Reg. Environ. Chang. 2017, 17, 2443-2453. [CrossRef]

131. ICEM. Strategic Environmental Assessment of Hydropower on the Mekong Mainstream. Summary of the Final Report; Mekong River Commission: Vientiane, Laos, 2010.

132. Wilmsen, B. Progress, problems, and prospects of dam-induced displacement and resettlement in China. China Inf. 2011, 25, 139-164. [CrossRef]

133. Urban, F.; Mohan, G.; Cook, S. China as a new shaper of international development: The environmental implications. Environ. Dev. Sustain. 2013, 15, 257-263. [CrossRef]

134. Olson, K.R.; Morton, L.R. Tonle Sap Lake and river and confluence with the Mekong River in Cambodia. J. Soil Water Conserv. 2018, 73, 60-66. [CrossRef]

135. Joffre, O.M.; Pant, J.; Somony, T.; Chantrea, B.; Viseth, H. Transforming Aquaculture in Cambodia through Introduction of Improved Tilapia; WorldFish: Penang, Malaysia, 2019.

136. Lang, O. Current status of sustainable agriculture in Cambodia. In Resource Enhancement and Sustainable Aquaculture Practices in Southeast Asia: Challenges in Responsible Production of Aquatic Species; Romana-Egua, R.R., Parado-Estepa, F.D., Salayo, N.D., Lebata-Ramos, J.H., Eds.; Southeast Asian Fisheries Development Center: Tigbauan, Philippines, 2014; pp. 27-40.

137. Gain, A.K.; Giupponi, C. Impact of the Farakka Dam on thresholds of the hydrologic flow regime in the lower Ganges River basin (Bangladesh). Water 2014, 6, 2501-2518. [CrossRef]

138. Hennig, T. Damming transnational Ayeyarwady basin. Hydropower and the water-energy nexus. Renew. Sust. Energy Rev. 2016, 65, 1232-1246. [CrossRef]

139. Chen, D.; Li, X.; Saito, Y.; Liu, J.P. Recent evolution of the Irrawaddy (Ayeyarwady) delta and the impacts of anthropogenic activities: A review and remote sensing survey. Geomorphology 2020, 365, 107231. [CrossRef]

140. Do, P.; Tian, F.; Zhu, T.; Zohidov, B.; Ni, G.; Lu, H.; Liu, H. Exploring synergies in the water-food-energy nexus by using an integrated hydro-economic optimization model for the Lancang-Mekong River basin. Sci. Total Environ. 2020, 728, 137996. [CrossRef] [PubMed]

141. Kautsky, N.; Berg, H.; Folke, C.; Larsson, J.; Troell, M. Ecological footprint for assessment of resource use and development limitations in shrimp and tilapia aquaculture. Aquacult. Res. 1997, 28, 753-766. [CrossRef]

142. Tacon, A.G.J.; Hasan, M.R.; Metian, M. Demand and Supply of Feed Ingredients from Farmed Fish. and Crustaceans; United Nations Food and Agriculture Organization: Rome, Italy, 2011. 
143. Shepherd, C.J.; Jackson, A.J. Global fishmeal and fish-oil supply: Inputs, outputs and markets. Fish. Biol. 2013, 83, 1046-1066. [CrossRef] [PubMed]

144. Tacon, A.G.J.; Hasan, M.R. Global synthesis of feeds and nutrients for sustainable aquaculture development. In Study and Analysis of Feeds and Fertilizers for Sustainable Aquaculture Development; Hasan, M.R., Hecht, T., De Silva, S.S., Tacon, A.G.J., Eds.; United Nations Food and Agriculture Organization: Rome, Italy, 2007.

145. Tveterås, S.; Tveterås, R. The global competition for wild fish resources between livestock and aquaculture. J. Agric. Econ. 2010, 61, 381-397. [CrossRef]

146. Han, D.; Shan, X.; Zhang, W.; Chen, Y.; Wang, Q.; Zhongjie, L.; Zhang, G.; Xu, P.; Li, J.; Xie, S.; et al. A revisit to fishmeal usage and associated consequences in Chinese aquaculture. Rev. Aquacult. 2018, 10, 493-507. [CrossRef]

147. Pahlow, M.; van Oel, P.R.; Mekonnen, M.M.; Hoekstra, A.Y. Increasing pressure on freshwater resources due to terrestrial feed ingredients for aquaculture production. Sci. Total Environ. 2015, 536, 847-857. [CrossRef]

148. Malcorps, W.; Kok, B.; Land, M.V.; Fritz, M.; Van Doren, D.; Servin, K.; Van Der Heijden, P.; Palmer, R.; Auchterlonie, N.A.; Rietkerk, M.; et al. The sustainability conundrum of fishmeal substitution by plant ingredients in shrimp feeds. Sustainability 2019, 11, 1212. [CrossRef]

149. Fry, J.P.; Mailloux, N.A.; Love, D.C.; Milli, M.C.; Cao, L. Feed conversion efficiency in aquaculture: Do we measure it correctly? Environ. Res. Lett. 2018, 13, 024017. [CrossRef]

150. Hua, K.; Cobcroft, J.M.; Cole, A.; Condon, K. The future of aquatic protein: Implications for protein sources in aquaculture diets. One Earth 2019, 1, 316-329. [CrossRef]

151. Mo, W.Y.; Man, Y.B.; Wong, M.H. Use of food waste, fish waste and food processing waste for China's aquaculture industry: Needs and challenge. Sci. Total Environ. 2018, 613-614, 635-643. [CrossRef]

152. Miao, W.; Yuan, X. The carp farming industry in China-An overview. In Species and System Selection for Sustainable Aquaculture; Leung, P., Lee, C., O’Bryen, P.J., Eds.; Blackwell Publishing: Ames, IA, USA, 2007; pp. 269-282.

153. Verdegem, M.C.J.; Bosma, R.H.; Verreth, J.A. Reducing water use for animal production through aquaculture. Int. J. Water Resourc. Devel. 2006, 22, 101-113. [CrossRef]

154. Mackay, K.D. (Ed.) Rice-Fish. Culture in China. International Development Research Centre: Ottawa, ON, Canada, 1995.

155. Fernando, C.H. Rice field ecology and fish culture-An overview. Hydrobiologia 1993, 259, 91-113. [CrossRef]

156. Little, D.C.; Edwards, P. Integrated Livestock-Fish. Farming Systems; United Nations Food and Agriculture Organization: Rome, Italy, 2003.

157. Gupta, M.V.; Sollows, J.D.; Mazid, M.A.; Rahman, A.; Hussain, M.G.; Dey, M.M. Economics and adoption patterns of integrated rice-fish farming in Bangladesh. In Rural Aquaculture; Edwards, P., Little, D.C., Demaine, H., Eds.; CABI Publishing: New York, NY, USA, 2002; pp. 41-54.

158. Mohanty, R.K.; Verma, H.N.; Brahmanand, P.S. Performance evaluation of rice-fish integration system in rainfed medium land ecosystem. Aquaculture 2004, 230, 125-135. [CrossRef]

159. Little, D.C.; Surintaraseree, P.; Innes-Taylor, N. Fish culture in rainfed rice fields of northeast Thailand. Aquaculture 1996, 140, 295-321. [CrossRef]

160. Gregory, R.; Guttman, H. The ricefield catch and rural food security. In Rural Aquaculture; Edwards, P., Little, D.C., Demaine, H., Eds.; CABI Publishing: New York, NY, USA, 2002; pp. 1-14.

161. Dey, M.M.; Spielman, D.J.; Haque, A.B.M.M.; Rahman, M.S.; Valmonte-Santos, R.A. Change and Diversity in Smallholder Rice-Fish. Systems. Recent Evidence from Bangladesh; International Food Policy Research Institute: Washington, DC, USA, 2012.

162. Haroon, A.K.Y.; Pittman, K.A. Rice-fish culture: Feeding, growth and yield of two size classes of Puntius gonionotus Bleeker and Oreochromis spp. in Bangladesh. Aquaculture 1997, 154, 261-281. [CrossRef]

163. Karimov, B. An overview on desert aquaculture in Central Asia (Aral Sea Drainage Basin). In Aquaculture in Desert and Arid Lands, Development Constraints and Opportunities; Crespi, V., Lovatelli, A., Eds.; United Nations Food and Agriculture Organization: Rome, Italy, 2011; pp. 61-84.

164. Halwart, M.; Gupta, M.V. (Eds.) Culture of Fish in Rice Fields; United Nations Food and Agriculture Organization: Rome, Italy, 2004.

165. Uphoff, N. The System of Rice Intensification (SRI): IRC Newsletter No. 55, Using Alternative Cultural Practices to Increase Rice Production and Profitability from Existing Yield Potentials; United Nations Food and Agricultural Organization: Rome, Italy, 2012. 
166. Kunda, M.; Azim, M.E.; Wahab, M.A.; Dewan, S.; Roos, N.; Thilsted, S.H. Potential of mixed culture of freshwater prawn (Macrobrachium rosenbergii) and self-recruiting small species mola (Amblypharyngodon mola) in rotational rice-fish/prawn culture systems in Bangladesh. Aquacult. Res. 2009, 39, 506-517. [CrossRef]

167. Miao, W.; Ge, X. Freshwater prawn culture in China: An overview. Aquacult. Asia 2002, 7, 9-12.

168. Giap, D.H.; Yi, Y.; Lin, C.K. Effects of different fertilization and feeding regimes on the production of integrated farming of rice and prawn Macrobrachium rosenbergii (De Man). Aquacult. Res. 2005, 36, 292-299. [CrossRef]

169. Koesoemadinata, S.; Costa-Pierce, B.A. Development of rice-fish farming in Indonesia: Past, present and future. In Rice-Fish Research and Development in Asia; Dela Cruz, C.R., Lightfoot, B.A., Costa-Pierce, B.A., Carangal, V.R., Bimbao, M.P., Eds.; International Center for Living Aquatic Resources: Penang, Malaysia, 1992; pp. 45-62.

170. Ahmed, N.; Wahab, M.A.; Thilsted, S.H. Integrated aquaculture-agriculture systems in Bangladesh: Potential for sustainable livelihoods and nutritional security of the rural poor. Aquacult. Asia 1992, 12, 14-22.

171. Karim, M.; Little, D.C.; Kabir, M.S.; Verdegem, M.J.C. Enhancing benefits from polycultures including tilapia (Oreochromis niloticus) within integrated pond-dike systems: A participatory trial with households of varying socio-economic level in rural and peri-urban areas of Bangladesh. Aquaculture 2011, 314, 225-235. [CrossRef]

172. Nhan, D.K.; Phong, L.T.; Verdegem, M.; Duong, L.T.; Bosma, R.H.; Little, D.C. Integrated fresh water aquaculture, crop and livestock production in the Mekong delta, Vietnam: Determinants and the role of the pond. Agric. Syst. 2007, 94, 445-458. [CrossRef]

173. Pant, J.; Demaine, H.; Edwards, P. Assessment of the aquaculture subsystem in integrated agriculture-aquaculture systems in Northeast Thailand. Aquacult. Res. 2004, 35, 289-298. [CrossRef]

174. Mariscal-Lagarda, M.M.; Páez-Osuna, F.; Esquer-Méndez, J.L.; Guerrero-Monroy, I.; Del Vivar, A.R.; Félix-Gastelum, R. Integrated culture of white shrimp (Litopenaeus vannamei) and tomato (Lycopersicon esculentum Mill) with low salinity groundwater: Management and production. Aquaculture 2012, 366-367, 76-84. [CrossRef]

175. Phong, L.; Van Dam, A.; Udo, H.; Van Mensvoort, M.; Tri, L.; Steenstra, F.; Van Der Zijpp, A. An agro-ecological evaluation of aquaculture integration into farming systems of the Mekong Delta. Agric. Ecosyst. Environ. 2010, 138, 232-241. [CrossRef]

176. Nhan, D.K.; Milstein, A.; Verdegem, M.C.J.; Verreth, J.A.V. Food inputs, water quality and nutrient accumulation in integrated pond systems: A multivariate approach. Aquaculture 2006, 261, 160-173. [CrossRef]

177. Mohri, H.; Lahoti, S.; Saito, O.; Mahalingam, A. Assessment of ecosystem services in homegarden systems in Indonesia, Sri Lanka, and Vietnam. Int. J. Agric. Sust. 2011, 5, 124-136. [CrossRef]

178. Atkins, M.; Byrd, K.A.; Pincus, L.; Naziri, D.; Yossa, R.; Thilsted, S. Integrating Fish., Tubers and Bananas in Food Systems: Opportunities and Constraints; WorldFish: Penang, Malaysia, 2020.

179. Edwards, P.; Little, D.C.; Demaine, H. Issues in rural aquaculture. In Rural Aquaculture; Edwards, P., Little, D.C., Demaine, H., Eds.; CABI Publishing: New York, NY, USA, 2002; pp. 323-340.

180. Pant, J.; Promthong, P.; Lin, C.K.; Demaine, H. Fertilisation of ponds with inorganic fertilisers: Low cost technologies for small-scale farmers. In Rural Aquaculture; Edwards, P., Little, D.C., Demaine, H., Eds.; CABI Publishing: New York, NY, USA, 2002; pp. 117-128.

181. Ruddle, K.; Zhong, G. Integrated Agriculture-Aquaculture in South. China. The Dike-Pond System of the Zhu Jiang Delta; Cambridge University Press: Cambridge, UK, 1988.

182. Ruddle, K.; Furtado, J.I.; Zhong, G.F.; Deng, H.Z. The mulberry dike-carp pond resource system of the Zhujiang (Pearl River) Delta, People's Republic of China; I. Environmental context and system overview. Appl. Geog. 1983, 3, 45-62. [CrossRef]

183. Lo, C.P. Environmental impact on the development of agricultural technology in China: The case of the dike-pond ('jitang') system of integrated agriculture-aquaculture in the Zhujiang Delta of China. Agric. Ecosyst. Environ. 1996, 60, 183-195. [CrossRef]

184. Liu, S.; Min, Q.; Jiao, W.; Liu, C.; Yin, J. Integrated emergy and economic evaluation of Huzhou mulberry-dyke and fish-pond systems. Sustainability 2018, 10, 3860. [CrossRef]

185. Zhang, J.; Dou, Y.Q.; Gui, Z.Z.; Li, L.; Zhao, Y.; Ren, Y.-L.; Wang, W.-Y.; Zhang, Z.-S. Mulberry-base-fish-pond, the typical model of sericultural circular economy in southern China. Sci. Sericult. 2010, 36, 470-474. (In Chinese) 
186. Gu, X.; Lou, L.; Liu, C.; Yu, Q. Jitang system: Research review and prospects. J. Nat. Resourc. 2018, 22, 709-720. (In Chinese) [CrossRef]

187. Astudillo, M.F.; Thalwitz, G.; Vollrath, F. Modern analysis of an ancient integrated farming arrangement: Life cycle assessment of a mulberry dyke and pond system. Int. J. Life Cycle Assess. 2015, 20, 1387-1398. [CrossRef]

188. Petr, T.; Ismukhanov, K.; Kamilov, B.; Umarov, P.D. Irrigation systems and their fisheries in the Aral Sea Basin, Central Asia. In Proceedings of the Second International Symposium on the Management of Large Rivers for Fisheries; Wellcome, R.L., Petr, T., Eds.; United Nations Food and Agricultural Organization: Rome, Italy, 2004; Volume 2, pp. 223-242.

189. Ismukhanov, K.; Mukhamedzhanov, V. The use of irrigation systems for sustainable production of agricultural and fish products in the Republic of Kazakhstan. In Fisheries in Irrigation Systems of Arid Asia; Petr, T., Ed.; United Nations Food and Agriculture Organization: Rome, Italy, 2004; pp. 101-114.

190. Zhiltsov, S.S.; Zhiltsova, M.S.; Medvedev, N.P.; Slizovskiy, D.Y. Water resources of Central Asia: Historical overview. In Water Resources in Central Asia: International Context; Zhiltsov, S.S., Zonn, I.S., Kostianoy, A.G., Semenov, A.V., Eds.; Springer: Cham, Switzerland, 2020; pp. 9-24.

191. Hamidov, A.; Helming, K.; Balla, D. Impact of agricultural land use in Central Asia: A review. Agron. Sustain. Devel. 2016, 36, 6. [CrossRef]

192. Kamilov, B. The use of irrigation systems for sustainable fish production: Uzbekistan. In Fisheries in Irrigation Systems of Arid Asia; Petr, T., Ed.; United Nations Food and Agriculture Organization: Rome, Italy, 2004; pp. 115-124.

193. Scott, J.; Rosen, M.R.; Saito, L.; Decker, D.L. The influence of irrigation water on the hydrology and lake water budgets of two small arid-climate lakes in Khorezm, Uzbekistan. J. Hydrol. 2011, 410, 114-125. [CrossRef]

194. Fernando, C.H.; Halwart, M. Possibilities for the integration of fish farming into irrigation systems. Fish. Manag. Ecol. 2000, 7, 45-54. [CrossRef]

195. Li, Q.; Gowing, J.W.; Mayilswami, C. Multiple-use management in a large irrigation system: An assessment of technical constraints to integrating aquaculture within irrigation canals. Irrig. Drain. 2005, 54, 31-42. [CrossRef]

196. Redding, T.A.; Midlen, A.B. Fish. Production in Irrigation Canals, A Review; Food and Agriculture Organization of the United Nations: Rome, Italy, 1990.

197. Wang-Erlandsson, L.; van der Ent, R.J.; Gordon, L.J.; Savenije, H.H.G. Contrasting roles of interception and transpiration in the hydrological cycle. Part 1: Temporal characteristics over land. Earth. Syst. Dynam. 2014, 5, 441-469. [CrossRef]

198. Karimov, B.; Kamilov, B.; Upare, M.; van Anrooy, R.; Bueno, P.; Shokhimardonov, D. Inland Capture Fisheries and Aquaculture in the Republic of Uzbekistan: Current Status and Planning; United Nations Food and Agriculture Organization: Rome, Italy, 2009.

199. Timirkhanov, S.; Chaikin, B.; Makhambetova, Z.; Thorpe, A.; van Anrooy, R. Fisheries and Aquaculture in the Republic of Kazakhstan: A review; United Nations Food and Agriculture Organization: Rome, Italy, 2010.

200. Karimov, B.K.; Matthies, M.; Kamilov, B.G. Unconventional water resources of agricultural origin and their re-utilization potential for development of desert land aquaculture in the Aral Sea basin. In The Global Water System in the Anthropocene; Bhaduri, A., Bogardi, J., Leentvaar, J., Marx, S., Eds.; Springer: Heidelberg, Germany, 2014; pp. 143-159.

201. Kostianoy, A.B.; Kosarev, A.N. (Eds.) The Aral Sea Environment; Springer: Berlin, Germany, 2010.

202. Kulikov, Y.V.; Assylbekova, Z. The fisheries and aquaculture sector in Kazakhstan: Significant potential to be realized. Eurofish Mag. 2020, 3, 53-55.

203. Badryzlova, N.; Koishybayeva, S.; Assylbekova, S.; Isbekov, K. Technology of formation of replacement-brood stock of pikeperch in conditions of fish farms in Kazakhstan. Eur. Asian J. BioSci. 2020, 14, 441-447.

204. Graham, N.A.; Pueppke, S.G.; Uderbayev, T. The current status and future of Central Asia's fish and fisheries: Confronting a wicked problem. Water 2017, 9, 701. [CrossRef]

205. Zhiltsov, S.S.; Zonn, I.S.; Nogmova, A.S.; Shtol, V.V. Water resource policy in Kazakhstan. In Water Resources in Central Asia: International Context; Zhiltsov, S.S., Zonn, I.S., Kostianoy, A.G., Semenov, A.V., Eds.; Springer: Cham, Switzerland, 2020; pp. 169-186. 
206. Wecker, B.; Karimov, B.; Kamilov, B.; Waller, U. Sustainable Aquaculture in Recirculating Systems, Feasibility Study for the Catchment Area of the Aral Sea; Institut für Umweltsystemforschung, Universität Osnabrück: Osnabrück, Germany, 2007.

207. Crespi, V.; Lovatelli, A. Global desert aquaculture at a glance. In Aquaculture in Desert and Arid Lands, Development Constraints and Opportunities; Crespi, V., Lovatelli, A., Eds.; United Nations Food and Agriculture Organization: Rome, Italy, 2011; pp. 25-38.

208. Crootof, A.; Mullabaev, N.; Saito, L.; Atwell, L.; Rosen, M.R.; Bekchonova, M.; Ginatullina, E.; Scott, J.; Chandra, S.; Nishonov, B.; et al. Hydroecological condition and potential for aquaculture in lakes of the arid region of Khorezm, Uzbekistan. J. Arid. Environ. 2015, 117, 37-46. [CrossRef]

209. Conrad, C.; Kaiser, B.O.; Lamers, J.P.A. Quantifying water volumes of small lakes in the inner Aral Sea Basin, Central Asia, and their potential for reaching food and water security. Earth Environ. Sci. 2016, 75, 952. [CrossRef]

210. Sutton, W.; Diffey, S.; Peter, T. Innovations in Fisheries Management for Kazakhstan; World Bank: Washington, DC, USA, 2005.

211. FAO, FAOLEX. Decree on Measures to Improve the Management System of the Fishing Industry; No. 2939; FAO, FAOLEX: Tashkent, Republic of Uzbekistan, 2017. (In Uzbek)

212. Cottrell, R.S.; Nash, K.L.; Halpern, B.S.; Remenyi, T.; Corney, S.; Fleming, A.; Fulton, E.A.; Hornborg, S.; Johne, A.; Watson, R.A.; et al. Food production shocks across land and sea. Nat. Sust. 2019, 2, 130-137. [CrossRef]

213. Pullin, R.S.V.; Shehadeh, Z.X. (Eds.) Integrated Agriculture-Aquaculture Farming Systems; ICLARM: Manila, Philippines, 1980.

214. Zajdband, A.D. Integrated agri-aquaculture systems. In Genetics, Biofuels and Local Farming Systems; Lichtfouse, E., Ed.; Springer: Dordrecht, Netherlands, 2011; pp. 87-128.

215. Yao, L.; Zhao, M.; Xu, T. China's water-saving irrigation management system: Policy, implementation, and challenge. Sustainability 2017, 9, 2339. [CrossRef]

216. Haylor, G.; Bhutta, M.S. The role of aquaculture in the sustainable development of irrigated farming systems in Punjab, Pakistan. Aquacult. Res. 2008, 28, 691-705. [CrossRef]

217. Zhiltsov, S.S.; Zonn, I.S.; Kostianoy, G.; Semenov, A.K. Conclusions. In Water Resources in Central Asia: International Context; Zhiltsov, S.S., Zonn, I.S., Kostianoy, A.G., Semenov, A.V., Eds.; Springer: Cham, Switzerland, 2020; pp. 263-275.

218. Petrov, G. Conflict of interest between hydropower and irrigation in Central Asia. Its causes and ways of overcoming. Central Asia Cauc. 2010, 13, 59-72. (In Russian)

219. Pullin, R.S.V. An overview of environmental issues in developing country agriculture. In Environment and Aquaculture in Developing Countries; Pullin, R.S.V., Rosenthal, H., Maclean, J.L., Eds.; ICLARM: Manila, Philippines, 1993; pp. 1-19.

220. Tezzo, X.; Bush, S.R.; Oosterveer, P.; Belton, B. Food system perspective on fisheries and aquaculture development in Asia. Agric. Hum. Values 2020, 1-18. [CrossRef]

221. Dugan, P.; Dey, M.M.; Sugunan, V.V. Fisheries and water productivity in tropical river basins: Enhancing food security and livelihoods by managing water for fish. Agric. Water Manag. 2006, 80, 262-275. [CrossRef]

222. Haylor, G.S. Fish production from engineered waters in developing countries. In Recent Advances in Aquaculture; Muir, J.E., Roberts, R.J., Eds.; Blackwell Scientific Publications: Oxford, UK, 1994; pp. 1-103.

223. Intralawan, A.; Smajgl, A.; McConnell, W.; Ahlquist, D.B.; Ward, J.; Kramer, D.B. Reviewing benefits and costs of hydropower development evidence from the Lower Mekong River Basin. Wires Water 2019, 6, e1347. [CrossRef]

224. Costa-Pierce, B.A. Sustainable ecological aquaculture systems: The need for a new social contract for aquaculture development. Mar. Tech. Soc. J. 2010, 44, 88-112. [CrossRef] 
225. Krause, G.; Brugere, C.; Diedrich, A.; Ebeling, M.W.; Ferse, S.C.; Mikkelsen, E.; Agúndez, J.A.P.; Stead, S.M.; Stybel, N.; Troell, M. A revolution without people? Closing the people-policy gap in aquaculture development. Aquaculture 2015, 447, 44-55. [CrossRef]

226. Thomas, K.A. The problem with solutions: Development failures in Bangladesh and the interests they obscure. Ann. Amer. Assoc. Geog. 2020, 110, 1631-1651. [CrossRef]

227. Nguyen, Q.H.; Tran, D.D.; Dang, K.K.; Korbee, D. Land-use dynamics in the Mekong delta: From a national policy to livelihood sustainability. Sust. Devel. 2020, 28, 448-467. [CrossRef]

228. Bush, S.R.; Belton, B.; Little, D.C.; Islam, M.S. Emerging trends in aquaculture value chain research. Aquaculture 2019, 498, 428-434. [CrossRef]

229. Toufique, K.A.; Gregory, R. Common waters and private lands: Distributional impacts of floodplain aquaculture in Bangladesh. Food Policy 2008, 33, 587-594. [CrossRef]

230. Rasmussen, R.S.; Morrissey, M.T. Biotechnology in aquaculture: Transgenics and polyploidy. Comp. Rev. Food Sci. Food Safety 2007, 6, 2-16. [CrossRef]

231. Houston, R.D.; Bean, T.P.; Macqueen, D.J.; Gundappa, M.K.; Jin, Y.H.; Jenkins, T.L.; Selly, S.L.C.; Martin, S.A.M.; Stevens, J.R.; Santos, E.M.; et al. Harnessing genomics to fast track genetic improvement in aquaculture. Nature Rev. Genet. 2020, 21, 389-409. [CrossRef]

232. Biswal, A.K.; Shamim, M.; Cruzado, K.; Soriano, G.; Ghatak, A.; Toleco, M.; Vikram, P. Role of biotechnology in rice production. In Rice Production Worldwide; Chauhan, B., Jabran, K., Mahajan, G., Eds.; Springer: Cham, Switzerland, 2017; pp. 487-547.

233. Henriksson, P.J.G.; Belton, B.; Murshed-e-Jahan, K.; Rico, A. Measuring the potential for sustainable intensification of aquaculture in Bangladesh using life cycle assessment. Proc. Nat. Acad. Sci. USA 2018, 115, 2958-2963. [CrossRef]

234. Sears, L.; Caparelli, J.; Lee, C.; Pan, D.; Strandberg, G.; Vuu, L.; Lawell, C.-Y.C.L. Jevons' Paradox and efficient irrigation technology. Sustainability 2018, 10, 1590. [CrossRef]

235. Pueppke, S.G.; Zhang, Q.; Nurtazin, S.T. Irrigation in the Ili River basin of Central Asia: From ditches to dams to diversion. Water 2018, 10, 1650. [CrossRef]

236. Dumont, A.; Mayor, B.; López-Gunn, E. Is the rebound effect or Jevons paradox a useful concept for better management of water resources? Insights from the irrigation modernization process in Spain. Aquat. Proc. 2012, 1, 64-76. [CrossRef]

237. Pfeiffer, L.; Lin, C.Y.C. Does efficient irrigation technology lead to reduced groundwater extraction? Empirical evidence. J. Environ. Econ. Manag. 2014, 67, 189-208. [CrossRef]

238. Grafton, R.Q.; Williams, J.; Perry, C.J.; Molle, F.; Ringler, C.; Steduto, P.; Udall, B.; Wheeler, S.A.; Wang, Y.; Garrick, D.; et al. The paradox of irrigation efficiency. Science 2018, 361, 748-750. [CrossRef] [PubMed]

239. Fierro-Sañudo, J.F.; Rodriguez-Montes de Oca, G.A.; Páez-Osuna, F. Co-culture of shrimp with commercially important plants: A review. Rev. Aquacult 2020, in press. [CrossRef]

240. Barange, M.; Bahri, T.; Beveridge, M.C.M.; Cochrane, K.L.; Funge-Smith, S.; Poulain, F. Impacts of Climate Change on Fisheries and Aquaculture: Synthesis of Current Knowledge, Adaptation and Mitigation Options; United Nations Food and Agriculture Organization: Rome, Italy, 2018.

241. Reid, G.K.; Gurney-Smith, H.J.; Flaherty, M.; Garber, A.F.; Forster, I.; Brewer-Dalton, K.; Knowler, D.; Marcogliese, D.J.; Chopin, T.; Moccia, R.D.; et al. Climate change and aquaculture: Considering adaptation potential. Aquacult. Environ. Interact. 2019, 11, 603-624. [CrossRef]

242. Henry, R.J. Innovations in plant genetics adapting agriculture to climate change. Curr. Opinion Plant Biol. 2020, 56, 168-173. [CrossRef]

243. Chen, S.; Gong, B. Response and adaptation of agriculture to climate change: Evidence from China. J. Devel. Econ. 2020, in press. [CrossRef]

244. Dara, A.; Baumann, M.; Freitag, M.; Hölzel, N.; Hostert, P.; Kamp, J.; Müller, D.; Prischchepov, A.V.; Kuemmerle, T. Annual Landsat time series reveal post-Soviet changes in grazing pressure. Remote Sens. Environ. 2020, 239, 111667. [CrossRef]

245. Molden, D.; Oweis, T.; Steduto, P.; Bindraban, P.; Hanjra, M.A.; Kijne, J. Improving agricultural water productivity: Between optimism and caution. Agric. Water Manag. 2010, 97, 528-535. [CrossRef] 
246. Jennings, S.; Stentiford, G.; Leocadio, A.M.; Jeffery, K.R.; Metcalfe, J.D.; Katsiadaki, I.; Auchterlonie, N.A.; Mangi, S.C.; Pinnegar, J.K.; Ellis, T.; et al. Aquatic food security: Insights into challenges and solutions from an analysis of interactions between fisheries, aquaculture, food safety, human health, fish and human welfare, economy and environment. Fish. Fish. 2016, 17, 893-938. [CrossRef]

247. Mondal, M.A.H.; Sikdar, M.M.H.; Mahbub Morshed Khan, A.B.M.; Alam, M.J. Poverty alleviation through aquaculture: An inquiry into some selected areas of rural Bangladesh. Haya Saudi J. Life Sci. 2019, 4, 287-297. [CrossRef]

(C) 2020 by the authors. Licensee MDPI, Basel, Switzerland. This article is an open access article distributed under the terms and conditions of the Creative Commons Attribution (CC BY) license (http://creativecommons.org/licenses/by/4.0/). 